\title{
Renewable Energy in the International Arena: Legal Aspects and Cooperation
}

\author{
Marco Citelli, Marco Barassi, Ksenia Belykh*
}

DOI: $10.21827 / 5 a 86 a 7 c 841628$

\section{Keywords}

RENEWABLE ENERGY; INTERNATIONAL ENVIRONMENTAL LAW; WTO; INTERNATIONAL DISPUTES ; INTERNATIONAL COOPERATION; IRENA

\begin{abstract}
This article aims at investigating the relevant aspects of international law and cooperation in the field of renewable energy. Part I provides an overview of the multiple soft law developments within and outside the UN framework as well as an assessment of a chosen set of extant treaty obligations either fostering or potentially constraining the development of the renewable energy sector. In light of these norms, Part II analyses a series of recent cases and international disputes triggered by non-environmental interests and rights allegedly impaired by the implementation of certain renewable energy-related plans and projects. In particular, this section considers the compatibility of renewable energy development with extant norms in the areas of human rights (ECHR), procedural environmental rights (Aarhus Convention) and international trade law (WTO). Despite the scarcity of binding norms on renewable energy generation and the persistence of various factors leading to disputes, global cooperation in the field of renewable energy is gaining momentum. Starting with an overview on CDM renewable energy projects under the Kyoto Protocol, Part III then shifts to the latest developments in renewable energy cooperation prompted respectively by the creation of the International Renewable Energy Agency (IRENA) and by the growing number of transnational private partnerships operating in the field of renewables.
\end{abstract}

\section{Is There an International Legal Framework for Renewable Energy? An Overview on the Current Status of Soft Law and Treaty Developments}

\section{I.1. Renewable Energy Gaining Ground on the Global Sustainable Development Agenda}

Renewable energy has always been an agenda item at the global environmental conferences convened by the UN and other international fora. However, issues such as the dissemination of its related technologies as well as the relationship between

* Marco Citelli, Ph.D in International Law and Economics at Bocconi University (Part I: paragraph 1.1; Part II: paragraphs 2.1 and 2.2.), Marco Barassi, Ph.D Candidate in International Law and Economics at Bocconi University (Part I: paragraph 1.2; Part II: paragraph 2.3. and 2.4.), Ksenia Belykh, Ph.D Candidate in International Law and Economics at Bocconi University (Part III). 
renewable energy and the principle of sustainable development or the creation of international rules binding States to their use were never fully explored on those occasions. In order to have a full picture of the international legal developments on this matter, the first step is to weigh the interest that the international community has collectively acknowledged to the use of renewable energy by means of soft law. Our starting point is the recognition of the scarcity of both binding and non-binding international legal instruments on renewable energy due to the persistency of interests sustaining the exploitation of traditional energy sources as well as of market imperfections and technical constraints hampering a wider reliance on renewable energy. ${ }^{1}$ The 1987 Bruntland report by the World Commission on Environment and Development, considered as a milestone of international environmental law for providing a first definition of sustainable development, labelled renewable energy as an 'untapped potential' and considered that renewable energy should be the "foundation of the global energy structure during the 21st Century". ${ }^{2}$ However, UN Members participating at the 1992 Rio Conference on Environment and Development (UNCED) embraced only timidly the straightforward indication of the Bruntland Commission. In fact, among the Principles shaping the Rio Declaration, ${ }^{3}$ only a few are of a certain relevance to the renewable energy sector. Besides the Principle 2, which combines the sovereign right over natural resources with the prohibition of transboundary harm (sic utere tuo ut alienum non laedas), ${ }^{4}$ of particular relevance are Principle 17 , on environmental

1 Quadri, S., Lineamenti di diritto internazionale delle fonti di energia rinnovabile, Editoriale Scientifica, Napoli, 2008, 41; Redgwell, C., "International Legal Responses to the Challenges of a Lower-Carbon Future: Climate Change, Carbon Capture and Storage, and Biofuels", in: Zillman, D. N. et al., eds., Beyond the Carbon Economy: Energy Law in Transition, Oxford University Press, Oxford, 2008, 85-108, 100.

2 UN GA Resolution 427 (42), 4 August 1987, Report of the World Commission on Environment and Development (Bruntland Report), "Our Common Future", Chapter 7, para. 88. Sustainable development is defined as the 'development that meets the needs of the present without compromising the ability of future generations to meet their own needs'. International jurisprudence only contributed to enrich such definition to a limited extent, see Sands, P., "International Courts and the Application of the Concept of Sustainable Development", Max Planck UNYB, vol. 3, 1999, 389-405. In the ICJ, 25 September 1997, Gabcikovo-Nagymaros case/Hungary v. Slovakia, ICJ Reports 1997, the Court refrained from defining sustainable development as an international law principle. The "normative value" enjoyed by the concept was nevertheless highlighted, see Gabcikovo-Nagymaros Project/Hungary v. Slovakia, Separate Opinion of Vice-President Weeramantry, and eminently described as a "metaprinciple" exercising a kind of interstitial normativity, pushing and pulling the boundaries of true primary norms threatening to overlap and conflict with each other, see Lowe, A., "Sustainable Development and Unsustainable Arguments", in: Boyle, A. and Freestone, P., eds., International Law and Sustainable Development: Past Achievements and Future Challenges, Oxford University Press, Oxford, 1999, 31. A large part of the doctrine reasoned on the complexity of defining sustainable development in legal terms, see e.g. Pallemaerts, M., "The Future of Environmental Regulation: International "Environmental Law in the Age of Sustainable Development: a Critical Assessment of the UNCED Process", The Journal of Law and Commerce, vol. 15, 1996, 623-676, 630-634 and Di Monte, M., "Il principio dello sviluppo sostenibile: affermazione ed evoluzione”, in: Nascimbene, B. and Garofalo, L., eds., Studi su ambiente e diritto. Il diritto dell'Unione europea, Cacucci Editore, Bari, 2013, 49-62. Difficulties inherent to the implementation of the concept were recently addressed by Viñuales, J.E., "The Rise and Fall of Sustainable Development", RECIEL, vol. 22, ed. 1, 2013, 3-13.

3 United Nations Conference on Environment and Development, The 1992 Rio Declaration on Environment and Development, UN Doc. A/Conf.151/5/Rev.1, of 14 June 1992.

4 The customary nature of the 'no harm rule' has been affirmed by international jurisprudence, see ICJ, 8 July 1996, Legality of the Threat or Use of Nuclear Weapons, Advisory Opinion, ICJ Reports 1996, paras. 
impact assessments (EIA), and Principle 10, on access to justice and information in environmental matters. These Principles will be later explored, referring to some disputes involving the generation of energy from renewable sources.

Furthermore, no proper focus on energy appears in Agenda 21, where specific references on renewable energy can be tracked only in conjunction with the protection of the atmosphere. ${ }^{5}$ Therefore, during the process that led to the 2002 World Summit on Sustainable Development (WSSD), energy was identified as one of the areas requiring further efforts in order to fully implement Agenda 21. To this end, the "Water, Energy, Health, Agriculture and Biodiversity Working Group" (WEHAB-WG) proposed "A Framework for Action on Energy", ${ }^{6}$ extensively marking renewable energy as a key driver of sustainable development. However, WEHAB recommendations were only partially welcomed by the Johannesburg Plan of Implementation (JPoI) ${ }^{7}$ which was deprived by the participating delegations of a thematic section on energy issues. The JPoI, in fact, concentrates on renewables and energy efficiency as cross-cutting issues (for poverty eradication and in the context of the needed changes to the patterns of consumption and production). ${ }^{8}$ The choice made at the WSSD is ascribable to the preeminence accorded to developmental issues over the environmental ones as well as to the endorsement of the 2000 Millennium Developmental Goals (MDGs). ${ }^{9}$ To some extent, this was counterbalanced by the recommendation to implement the work carried out in 2001 by the UN Commission on Sustainable Development (CSD). ${ }^{10}$ CSD-9, in fact, had

29-30. It was observed, however, that state practice reveals inconsistencies between what is portrayed as a customary rule, on the one hand, and its effective implementation, on the other hand, see Munari, F. and Schiano Di Pepe, L., Tutela transnazionale dell'ambiente, Il Mulino, Bologna, 2012, 41. On the limited relevance of international custom to renewable energy, see Bradbrook, A., "The Development of Renewable Energy Technology and Energy Efficiency Measures through Public International Law", in: Zillman, D. N. et al., eds., Beyond the Carbon Economy: Energy Law in Transition, Oxford University Press, Oxford, 2008, 109-131, 112.

5 See Agenda 21, Chapter 9, para. 9.12(f), in Report of the United Nations Conference on Environment and Development: UN Doc. A/151/6/Rev.1, 1992, reprinted in 31 International Legal Materials, 1992, 881, <sustainabledevelopment.un.org/content/documents/Agenda21.pdf> (accessed 23 January 2014).

6 WEHAB-WG, "A Framework for Action on Energy", 2002. The initiative was promoted by the UN Secretary-General Kofi Annan, in response to UN GA A/RES/55/199 of 5 February 2001 demanding further implementation of Agenda 21, available online at <www.iisd.ca/wssd/download\%20files/wehab_energy.pdf> (accessed 9 April 2014).

7 Johannesburg Plan of Implementation (JPoI), in UN Report on the World Summit on Sustainable Development, Johannesburg, South Africa, 26 August-4 September 2002, A/CONF/199/20, 6-72, available online at <www.iisd.ca/wssd/download\%20files/wehab_energy.pdf> (accessed 24 April 2014).

8 Id., paras. 9(a)(e), 20. Instead, the WEHAB-WG also underlined the need for a 'dedicated global institution' with a specific mandate on assisting developing countries in the use of renewable energy, supra nt. 6, 12.

9 See Galizzi, P., "From Stockholm to New York, via Rio and Johannesburg: Has the Environment Lost its Way on the Global Agenda?", Fordham International Law Journal, vol. 29, ed. 5, 2005, 952-1008. GA Resolution 2 (55), 18 September 2000, the United Nations Millennium Declaration. The MDGs are aimed at eradicating global poverty by 2015. The omission of access to energy from the Millennium Declaration has been criticised by A. Bradbrook, supra nt. 4. The JPoI, instead, explicitly states that 'affordable and reliable energy services' are supportive of the goals established therein.

10 CSD-9, Report of the 9th session, 5 May 2000 and 16-27 April 2001, available online at <un.org/ga/search/view_doc.asp?symbol=E/CN.17/2001/19\%20(SUPP)\&Lang=E> (accessed 23 January 2014), E/CN.17/2001/19 and JPoI, supra nt. 7, para. 20. 
set the floor for international cooperation in the energy sector. Amongst its conclusions, premised on the acknowledgment that 'energy is central for achieving the goals of sustainable development" ${ }^{\text {'1 }}$ and that 'energy resources are plentiful, and environmentally sound technological options exist and should be made available by developing countries to developing countries' ${ }^{12}$ pursuant to the 'common but differentiated responsibilities' principle (CBDRs), ${ }^{13}$ some identify renewable energy as a key issue. The increased development, utilisation and dissemination of renewable energy technologies are seen as the main challenges, significantly, for developed and developing countries alike. ${ }^{14}$ Notwithstanding this recognition, in 2007 the CSD had to take note of the impossibility to reach a consensus on the need to adopt measurable targets for renewable energy. In fact, while praising the adoption of voluntary commitments by some countries, CSD-15 concluded that 'the mention of time-bound targets proved to be one of the areas in which agreement could not be reached'. ${ }^{15}$ Meaningful political commitments in the field of renewable energy are steadily lacking also from the acts adopted during the more recent 2012 Rio+20 UN Summit. ${ }^{16}$ Its final document, short of reflecting any State consensus on the recognition of a basic right to energy, conclusively affirmed the existing interlink between access to energy and sustainable as well as human development. ${ }^{17}$ On this

11 Id., Decision 9/1 on "Energy for sustainable development", para. 1. CSD-15 reinforced this conceptual knot affirming that 'energy is crucial' also for poverty eradication, for the MDGs and the implementation of the JpoI. See, E/CN.17/2007/15, available online at <un.org/ga/search/view_doc.asp?symbol=E/CN.17/2007/15(SUPP)\&Lang=E> （accessed 23 January 23).

12 Id., Decision 9/1, para. 3.

$13 I d$., paras. 5, 7. As pointed out, the CBDRs principle (Principle 7 of the Rio Declaration) does not enjoy legal autonomy for it must be translated for implementation into treaty-based norms establishing dual regimes for the attainment of environmental/developmental objectives, see Munari, F. and Schiano Di Pepe, L., supra nt. 4, 47. See also Pauwelyn, J., "'The End of Differentiated Treatment for Developing Countries? Lessons from the Trade and Climate Change Regimes", Review of European, Comparative and International Environmental Law, vol. 22, ed. 1, 2013, 29-41, calling for further differentiation so as to overcome the paradigm of developed/developing countries.

14 See Decision 9/1, para. 16. Amongst recommended actions, CSD-9 proposed the promotion of renewable natural resources (solar, wind, biomass, geothermal, hydro and ocean) to partially meet energy needs for sustainable development, para. 17(e), the development and use of indigenous sources of renewable energy, para. 17(g) and the development and implementation of measures to make renewable energy technologies more affordable, para. 17(h).

15 See E/CN.17/2007/15, supra nt. 11, para. 11, as also envisioned by Redgwell, C., supra nt. 1, 101. It has been recently suggested that "as energy governance will continue to follow the "bilateral model", progress in the multilateral negotiations toward decarbonisation will remain elusive because the fossil energy path made possible at bilateral level will predetermine the pace and effectiveness of the multilateral decarbonisation negotiation'. See Viñuales, J. E., supra nt. 2, 11.

16 Held in Rio de Janeiro, Brazil on 20-22 June 2012, focused, respectively, on green economy in the context of poverty eradication and on the enhancement of the international governance for sustainable development.

17 According to some, an individual right to energy (as an essential service) is implicitly recognised by the 1948 Universal Declaration of Human Rights and the 1966 Covenant on Economic, Social and Cultural Right and other Conventions, e.g. see Clerc, M., "2nd World Forum on the Right to Energy, Marrakech, 19-21 June 2004", Atoms for Peace: An International Journal, vol. 1, 2005, 1-73, 11-13 and Tully, S., "The Contribution of Human Rights to Universal Energy Access", Northwestern Journal of International Human Rights, vol. 1, 2006, 518-548, 536-539. 
premise, UN Members built their commitment to facilitate the access to energy services to the 1.4 billion people currently deprived thereof. ${ }^{18}$

However, no preferential footing in this respect seems to have been specifically acknowledged to the use of renewable energy. On the one hand, although its contribution is deemed important and thus encouraged, renewable energy technologies might not always pass the agreed-upon 'test' set in order to qualify for international financial cooperation as 'modern energy services'. ${ }^{19}$ On the other hand, the sovereign right of States to choose the energy mix they deem more appropriate to meet their legitimate developmental needs is left untouched (renewable energy and cleaner fossil fuel technologies are formally regarded as equal options for sustainable development).$^{20}$

The limited support for renewable energy emerging from the UN's soft law puzzle clashes with the greater activism independently shown by States favouring the proliferation of other ad hoc initiatives. Said activism is proved by the fact that from 2004 onwards already five International Renewable Energy Conferences (IRECs) have been held, respectively, by the Governments of Germany (Bonn), ${ }^{21}$ China in 2005 (Beijing BIREC) the United States in 2008 (Washington - WIREC), India in 2010 (Delhi DIREC) and the United Arab Emirates in 2013 (Abu Dhabi - ADIREC) on the issue of renewable energy. ${ }^{22}$ The first IREC was convened in Bonn and paved the way to its successors by producing a Declaration that already went well beyond what fragmentarily expressed by previous (and later) UN Conferences by clearly stating that

renewable energies combined with energy efficiency, can significantly contribute to sustainable development, to providing access to energy, especially for the poor, to mitigating greenhouse gas emissions, reducing harmful air pollutants, thereby creating new economic opportunities, and enhancing energy security through cooperation and collaboration. ${ }^{23}$

18 See GA Resolution 288 (66), 11 September 2012, para. 125.

$19 I d$., para.126, according to which they are to be provided 'in a reliable, affordable, economically viable and socially and environmentally accepted manner in developing countries'. This formula forged by the CDS-9 (Decision 9/1, paras. 3, 12, supra nt. 11, gathered consensus both at the WSSD, see JPoI, para. 20 (a) and Rio+20 Summit.

20 Id., para. 127.

$211^{\text {st }}$ International Renewable Energy Conference (Bonn) of 1-4 June 2004. 154 States took part in the Conference, portrayed as a 'historic opportunity for nations to unite toward the common goal of a more sustainable energy future'. Sawin, J. L., Mainstreaming Renewable Energy in the 21st Century, World Watch Paper 196, 2004, 10. Others raised doubts on the contribution of this 'soft structure' to the 'international advancement of renewable energy', see Hirschl, B., "International renewable energy policy - between marginalization and initial approaches", Energy Policy, vol. 37, 2009, 4407-4416.

22 IRECs are promoted by the non-governmental organization REN21 (infra $\S 3.2$ ), supported by renewable-energy sensitive governments as the Beijing International Renewable Energy Conference (BIREC) of 7-8 November 2005, the Washington International Renewable Energy Conference (WIREC) of 3-6 March 2008 (8.600 persons from 113 countries participated, but contrary to other IRECs, it did not lead to any declaration), the Delhi International Renewable Energy Conference (DIREC) of 27-29 October 2010 and the Abu Dhabi International Renewable Energy Conference (ADIREC) of 15-17 January 2013 closing the proceedings of IRENA's annual General Assembly. On IRENA, infra $\S 3.2$.

23 See "Political Declaration" of 4 June 2004, para. 1, available online at $<$ ren21.net/Portals/0/documents/irecs/renew2004/ Political_declaration_final.pdf> (accessed 23 January 2014). 
In Bonn, consensus was gathered also on the urgent need to increase the share of renewable energy in the total energy supply, and Participating States reaffirmed their commitment to achieving the MDGs. ${ }^{24}$ Subsequent Conferences followed suit on all these points. ${ }^{25}$ Beside this, a throughout look at the Declarations on renewable energy reveals some interesting traits. The first one is given by the constant reference to developments going on within the UN framework and to the institutional mechanisms provided therein. If Participating States at the Bonn Conference and BIREC expressed the willingness to avail themselves of the CSD ${ }^{26}$ at DIREC they backed up the UN Secretary General's Advisory Group on Energy and Climate Change (AGECC) by endorsing the goal of realizing the universal access to modern energy services by 2030 and supported the General Assembly's resolution to designate 2012 as the International Year of Energy Access. ${ }^{27}$ More recently, at ADIREC Participating States welcomed the Secretary General's Sustainable Energy For All initiative and supported the General Assembly's decision of designating 2014-2024 as the UN Decade of Sustainable Energy. ${ }^{28}$ The second trait, instead, is determined by the constant reference to the developments going on and the mechanisms instituted within the international climate change regime. Far from establishing any binding obligations concerning renewable energy technology use and quantified targets, Participating States attempted to build bridges with the Kyoto Protocol (KP) by initially pointing at the Clean Development Mechanism (CDM) as a viable tool in order to leverage public funds for private investments on renewable energy.$^{29}$ In the absence of post-Kyoto arrangements, States recalled the start-funding provision inserted in the 2009 Copenhagen Accord, ${ }^{30}$ and subsequently stressed the importance of funding for climate change mitigation by pointing at the Green Climate Fund as a catalyst for the advancement of renewable energy. ${ }^{31}$

24 Id., paras. 2, 3.

25 See BIREC Declaration, paras. 1, 3, DIREC Declaration, paras. 1, 45. However, while States at the Bonn Conference and BIREC emphasised the urgency to increase the share of renewable energy, in 2010 (DIREC) and 2013 (ADIREC) also began to note the steady growth of renewable energy occurring despite constraining factors (i.e. the global recession, lack of a new climate agreement).

26 In order to measure the step taken to boost renewable energy in the context of the JPoI, see Political Declaration, para. 8 and BIREC Declaration, para. 12.

27 See DIREC Declaration, paras. 6, 7. Besides universal energy access, AGECC also called for the reduction of energy intensity by 40 per cent by 2030. See the Secretary General's Advisory Group on Energy and Climate Change, "Energy for a Sustainable Future. Summary Report and Recommendations" of 28 November 2010, 8, available online at $<$ unido.org/fileadmin/user_media/Publications/download/AGECCsummaryreport.pdf> (accessed 23 January 2014) and GA Resolution 151 (65), 16 February 2011 on "International year of sustainable energy for all".

28 See ADIREC Declaration, paras. 6, 7 and GA Resolution 215 (67), 20 March 2013 on "Promotion of new and renewable sources of energy".

29 See Beijing Declaration, para. 9. On CDM, infra $§ 3.1$.

30 See DIREC Declaration, para. 11 and COP15 Decision 2/CP15 "Copenhagen Accord", available online at <unfccc.int/resource/docs/2009/cop15/eng/11a01.pdf\#page $=4>$ (accessed 23 January 2014).

31 See ADIREC Declaration, para. 10. 


\section{I.2. Between Promotion and Constraints: Renewable Energy in the Context of Regional and International Agreements}

The global environmental conferences addressed above proved unfruitful as to the development of substantial norms on the utilisation of renewable energy (i.e. defining the terms of international cooperation and/or setting quantified targets), reaching only second-best outcomes (i.e. the drafting of soft law declarations and the setting of broad policy targets). In some circumstances, however, States decided to bind themselves to rules directly addressing the renewable energy sector. This process of norm creation has been mainly facilitated at a regional level thanks to the participation of a small number of States. A number of global treaties, as we shall see, also entail norms applicable to/implementable through the developments in this field.

In the Eurasian context (between the EC and CIS States), cooperation in the energy sector, through the trade and investment liberalisation measures, was underpinned by the creation of a common legal framework. Started off with the adoption of the European Energy Charter (a political declaration), the framework was later augmented by Energy Charter Treaty (ECT) and its Protocol on Energy Efficiency. ${ }^{32}$ Article 19 ECT emerges as the only "environmental" provision of the Treaty requiring States to minimise environmental degradation, in the pursuit of sustainable development by, inter alia, having 'particular regard to improving energy efficiency, to developing and using renewable energy sources, to promoting the use of cleaner fuels and to employing technologies and technological means that reduce pollution'. ${ }^{33}$ The Protocol, instead, entails more meaningful obligations concerning the development of laws, policies and regulations (Article 3), energy efficiency strategies (Article 5) and programs (Article 8). ${ }^{34}$

Energy cooperation was also commenced in the context of the Convention on the Protection of the Alps ${ }^{35}$ when Contracting Parties concluded an Energy Protocol. ${ }^{36}$ Widening the use of renewable energy stands out both as a basic commitment (Article 2,

32 European Energy Charter, 98/181/EC, 17 April 1991, The Hague (the Netherlands); Energy Charter Treaty, 17 December 1994, Lisbon (Portugal), 1995, 34 ILM, 360; Protocol on Energy Efficiency, 17 December 1994, Lisbon (Portugal), 1995, 34 ILM, 446. The Conventional system of the ECT has been regarded as interesting for the development of international energy trade law, representing a considerable part of the 'energy acquis' of the EU, CIS States, Central Asian States and Turkey (see Marletta, M., Energia. Integrazione europea e cooperazione internazionale, Giappichelli, Torino, 2011, 351356), while criticised for not being informed by the principle of sustainability (see Bosselman, K., "Ethical Implications", in Bradbrook, A., The Law of Energy for Sustainable Development, Cambridge University Press, Cambridge, 2012, 91-92).

33 Energy Charter Treaty, Art. 19, para.1(d), assessed as a 'hesitant first step to the environmental goal of promoting renewable energy and energy efficiency in the international law arena', see Bradbrook, A., supra nt. 4, 118.

34 ECT-based model for cooperation underpinned action within the Economic Community of West African States (ECOWAS) where an Energy Efficiency Protocol was concluded, Dakar (Senegal), available online at <www.comm.ecowas.int/sec/en/protocoles/WA_EC_Protocol_English_DEFINITIF.pdf $\geq$ (accessed 31 January, 2003).

35 Convention on the Protection of the Alps, Salzburg (Austria), 7 November, 1991, available online at <www.alpconv.org/it/convention/framework/default.html>, March 1995 (accessed 5 May 2014).

36 Protocol on the Implementation of the Alpine Convention of 1991, Bled (Slovenia), 16 October 1998, described as an instrument of international law of great importance given the absence from this realm of legally binding rules in the energy sector in line with the principle of sustainable development, see Quadri, S., Energia sostenibile. Diritto internazionale, dell'Unione europea e interno, Giappichelli, Torino, $2012,39$. 
paragraph 1, c) and as a clear 'preference' of the Contracting Parties. In fact, while committing to domestic and transboundary EIA procedures in relation to 'the construction of new, large power plants and a significant increase in the capacity of existing ones' (Article 2, paragraph 2), the Protocol also acknowledges that the Alpine region 'lends itself to using renewable energy sources' (Article 2, paragraph 3), marking this as a key factor of cooperation. This is fortified by the presence of an ad hoc provision on 'renewable energy sources'. Article 6, in fact, establishes that these sources shall be given 'preferential treatment' by virtue of their environmentally friendly characteristics (paragraph 1), be exploited by decentralised plants (paragraph 2) ${ }^{37}$ used in combination with traditional technologies (paragraph 3) and rationally used as not to impair the sustainability of mountain forests (paragraph 4). ${ }^{38}$ Renewable energy, as mandated by the Protocol, shall be taken into account by Contracting Parties in order to produce energy savings (Article 5, paragraph 1, b), as well as a substitute for fossil-fuels when technically, economically and environmentally feasible (as expressly required for existing fossil-fuel thermal plants: Article 8, paragraph 2).

It has been argued that States' domestic jurisdiction has been eroded by international cooperation on energy issues. ${ }^{39}$ In the light of the provisions on renewable energy addressed above, however, this argument might need specification. On the one hand, the said provisions do not substantially bind States to undertake any definite course of action with respect to the use and dissemination of renewable energy since they rather set, in a broad fashion, the conditions for cooperation and assistance. On the other hand, in most cases, they are heavily qualified. Such conditions are also inherent to the obligations set under major MEAs, such as the United Nations Convention on Climate Change (UNFCCC) and the Kyoto Protocol. ${ }^{40}$ This Convention is relevant to renewable energy developments as far as its Contracting Parties are required to control their sources of anthropogenic GHG emissions and to favour climate change mitigation by adopting programs to these ends while also streamlining climate change, to the extent feasible, in the preparation of their social, economic and environmental initiatives. ${ }^{41}$ The Protocol, for its

37 The provision refers solely to the use of solar, biomass and hydro-power, suggesting that negotiating States might have experienced difficulties in finding consensus on the inclusion of other renewable sources (e.g. wind energy).

38 Sustainability of mountain ecosystems shall be also be preserved by the Contracting Parties in relation to the exploitation of hydroelectric powers, as established under Art. 7.

39 See Quadri, S., supra nt. 1, 24-25 and Quadri, S., supra nt. 36, 41. On the contrary, underlining the absence of an ongoing multilateral energy process, see, Hirschl, B., supra nt. 21, 4408. According to the prevailing doctrine, the erosion of domestic jurisdiction results from the accumulation of international obligations that a State decides to take on by virtue of treaty ratification, see D'Amato, A., "Domestic Jurisdiction", in: Bernhardt, R., Encyclopedia of Public International Law, Instalment 10, North-Holland, 1987, 132-136. If this holds true for bilateral agreements with rules on fossil fuels imports and exports, it appears less evident in respect of the rules on renewable energy generation (due also to the primarily local characteristic of said activity) as well as of those on the international cooperation for sustainable development (i.e. financial and technical assistance under the climate change regime), ultimately ascribable to initiatives undertaken pursuant to Chapter IX of the UN Charter.

40 United Nations Framework Convention on Climate Change (UNFCCC), 1992, New York (United States), 1771 UNTS, 107; Kyoto Protocol to the United Nations Framework Convention on Climate Change, 1997, Kyoto, Japan, available online at <unfccc.int/essential_background/kyoto_protocol/ items/1678.php> (accessed 5 May 2014).

41 See UNFCCC, Article 4, para. 1 (b) and (f). On the implicit relevance of these provisions to renewable energy production and dissemination, see Bradbrook, A., supra nt. 4, 116. 
part, mandates Annex I Parties to 'implement and/or further elaborate policies and measures in accordance with national circumstances' on research and development of renewable energy technologies. ${ }^{42}$ In this regard, it must be highlighted, however, that the Protocol provides its Contracting Parties with the possibility of undertaking additional efforts (complementing domestic ones) under the so-called 'flexibility mechanisms' in Articles 6 ('Joint Implementation') and 12 ('Clean Development Mechanism'). Although only indirectly related to the use of renewable energy technologies, these instruments, addressed as a matter of international cooperation, certainly hold the potential to sustain their increase in the world energy supply. ${ }^{43}$

There are, however, branches of international law relevant to the renewable energy field by virtue of the negative obligations imposed on the conduct of States. Such norms may affect States' policy choices when regulating the renewable energy sector. ${ }^{44}$ In this sense, particular relevance is to be attributed to the multilateral trade rules agreed upon in the context of the World Trade Organization (WTO). From an international trade standpoint, the increasing importance of the utilisation of clean technologies for the realisation of sustainable development results in a renewed interest toward the compatibility between 'green policies' and multilateral trade rules. Despite a reference to the importance of sustainable development in the WTO Agreement's Preamble ${ }^{45}$ the covered agreements do not provide for any specific discipline regulating trade in energyrelated products and services ${ }^{46}$ let alone the trade in clean energy technologies. As a consequence, their trade obeys the same multilateral rules other goods are subject to. ${ }^{47}$ The relevance of WTO rules in non-trade areas is demonstrated by the fact that, unlike other legally binding instruments (e.g. multilateral environmental agreements (MEAs)),

42 Emphasis added. See KP, Article 2, paragraph 1, (i) and (iv).

43 See Quadri, S., 2012, supra nt. 36, 94 and Chandler, W., "Technological implications", in: Bradbrook. A., ed., supra nt. 4, 99. The favor legis of international climate change law for renewable energy developments has also been acknowledged by the Italian Constitutional Court, see Italian Constitutional Court, Judgment n. 282, of 6 November 2009.

44 The United Nations Convention on the Law of the Sea, Montego Bay (Jamaica), 1982, 1883 UNTS, 3 , constitutes one example in this respect. For instance, Zedalis, R. J., International Energy Law. Rules Governing future exploration, exploitation and use of renewable resources, Ashgate, Farnham, 2000, reflected on the balance of rights and duties attributed to States for the use of marine natural resources like tidal, geothermal and wave energy, as struck by the rules variously applicable to the different sea areas.

45 The 1994 WTO Agreement, in its Preamble, refers to the need for its Contracting Parties to make 'optimal use of the world's resources in accordance with the objective of sustainable development, seeking both to protect and preserve the environment'. See Marrakesh Agreement establishing the World Trade Organization (WTO Agreement), LT/UR/A/2, Marrakesh , 15 April, 1994, Preamble, $1^{\text {st }}$ indent.

46 On the WTO relevance for trade in energy products and services, see Buonomenna, F., Diritto Internazionale dell'energia, sovranità territoriale e governance internazionali, Editoriale Scientifica, Napoli, 2012, 58-62.

47 Legal uncertainty still exists within the WTO as to whether energy constitutes a good under the GATT or a service subject to GATS obligations. In this sense, see Bigdeli, S. Z., "Incentive schemes to promote renewables and the WTO law of subsidies" in: Cottier, T., Nartova, O., Bigdeli, S. Z., International Trade Regulation and the Mitigation of Climate Change, Cambridge University Press, 2009, 177. On the energy trade and WTO rules, see. Selivanova, Y., "The WTO and energy, WTO rules and agreements of relevance for the energy sector", ICTSD N.1, 2007, 11 et seq. On WTO rules and the global energy governance, see the remarks of former WTO Secretary Lamy, P., at the Workshop on the Role of Intergovernmental Agreements in Energy Policy organised by the Energy Charter Secretariat, 29 April, 2013, available online at <www.wto.org/english/news_e/sppl_e/sppl279_e.htm> (accessed 16 February 2014). 
the WTO system provides for a well-functioning dispute settlement mechanism empowered not only to decide on the legality of certain national measures, but also to authorise the suspension of trade concessions whenever a breach of one of the WTO provisions by a respondent State results in economic damage to the industry of a complainant State. ${ }^{48}$ Moreover, under certain conditions, the system allows WTO Members to enact unilateral trade remedies. ${ }^{49}$

The lack of specific regulatory instruments within the WTO gives rise to two main sets of issues. One question WTO negotiators have been facing concerns the market access of renewable energy related products. The Doha Development Agenda (DDA), ${ }^{50}$ providing a specific section on 'trade and environment', calls WTO Members to negotiate the 'reduction or, as appropriate, elimination of tariff and non-tariff barriers to environmental goods and services (EGS)'. ${ }^{51}$ In relation to renewable energy, the breakthrough of this proposal would have the immediate effect of lowering the price of essential technologies for renewable energy generation. However, negotiations on EGS have immediately stalemated due to the impossibility of reaching consensus on a general definition of environmental goods and because of the WTO Members' tendency to propose lists of products solely reflecting the interests of their national industries. ${ }^{52}$ So far then, notwithstanding the general plea in the WTO Agreement Preamble to promote sustainable development and climate change mitigation, market access rules for EGS remain subject to the general WTO principle of non-discrimination enshrined in the WTO agreements and the general Lists of tariff concessions annexed to the Marrakesh Protocol. ${ }^{53}$ More importantly, pursuant to the Agreement on Subsidies and

48 Understanding on rules and procedures governing the settlement of disputes (DSU), WTO Agreement, LT/UR/A-2/DS/U/1, Annex 2, Article 22, available online at <docs.wto.org/dol2fe/Pages/FE_ Browse/FE_B_009.aspx> (accessed 16 February 2014).

49 Such possibility is provided for in GATT Article VI.2 and 3 and it has been further elaborated in subsequent interpretative agreements, infra nt. 54 and 55. According to the doctrine, this provision confers on WTO Members an implicit power to promptly re-establish the equilibrium achieved through multilateral negotiations. See, Picone, P., Ligustro A., Diritto dell'Organizzazione Mondiale del Commercio, CEDAM, Padova, 2001, 248.

50 The Doha Development Agenda (DDA) is the latest round of multilateral trade negotiations among WTO Members, See, WT/MIN(01)/DEC/1, Ministerial Declaration, 20 November, 2001.

$51 \quad I d$., para. 31(iii).

52 An internationally agreed definition of Environmental Goods and Services (EGS) does not yet exist. The OECD/Eurostat defined the industry of environmental goods and services as consisting of 'activities which produce goods and services to measure, prevent, limit, minimise or correct environmental damage to water, air and soil, as well as problems related to waste, noise and ecosystems. This includes cleaner technologies, products and services that reduce environmental risk and minimise pollution and resource use. See, OECD/Eurostat, "The environmental goods \& services industry", Manual for data collection and analysis, OECD Publication service, 1999, 9. See also, OECD, "Opening Markets for Environmental Goods and Services", Policy Brief, September 2005, 5. Some progress has been achieved (outside the WTO), in the context of the Asia-Pacific Economic Cooperation (APEC). In 2012 APEC leaders committed to reduce to 5\% (or less) the duties applied to a specific list of environmental goods by the end of 2015. See, 20th APEC Economic Leaders Declaration, Annex C, available online at <apec2012.ru> (accessed 5 May 2014).

53 The principle of non-discrimination in trade in goods and services is declared, respectively, in Arts. I and III GATT and Arts. II and XVII GATS. However, under the GATS, national treatment obligations (Art. XVII) are applicable only where Members undertake specific commitments. 
Countervailing Measures (ASCM) ${ }^{54}$ and the Anti-Dumping Agreement (ADA), ${ }^{55}$ environmental products are not immune from unilateral and multilateral actions if it is demonstrated that they have benefited from export subsidisation or illegal dumping practices. ${ }^{56}$ In this sense, mounting trade tensions between major producers and importers of renewable energy technologies have already resulted in unilateral actions aimed at countervailing the negative effects of (alleged) export subsidisation and dumping practices. ${ }^{57}$

The second issue resulting from the lack of a WTO discipline tailored to renewable energy relates to the uncertainty about the compliance to the ASCM of financial incentive schemes enacted by governments as a response to energy security and climate change concerns. ${ }^{58}$ At the present status of technological development, government intervention (either direct or indirect) is a crucial component of many public policies aiming at stimulating the dissemination of renewable energy technologies. ${ }^{59}$ Under the ASCM perspective, this practice can raise particular problems. Indeed, even if explicit prohibitions are exclusively provided for with regard to two types of measures (export and import substitution subsidies as established by Article 3.1), other types of specific subsidisation, ${ }^{60}$ regardless of their stated goals, can be 'actionable' through the DSB if resulting in an 'adverse effect' within the meaning of Article 5 and 6 of the ASCM. ${ }^{61}$ At

54 Agreement on Subsidies and Countervailing Measures (ASCM), WTO Agreement, LT/UR/A-1A/9, Annex 1A, available online at <docs.wto.org/dol2fe/Pages/FE_Browse/FE_B_009.aspx> (accessed 16 February 2014).

55 Agreement on the implementation of Article VI of the General Agreement on Tariffs and Trade 1994 (ADA), WTO Agreement, LT/UR/A-1A/3, Annex 1A, available online at <docs.wto.org/dol2fe/ Pages/FE_Browse/FE_B_009.aspx> (accessed 16 February 2014).

56 In the event of exports supported by subsidies, WTO Members considered to have suffered a nullification or impairment of the benefits accrued under the Agreements, can recur to the DSB or, in certain circumstances, unilaterally adopt countervailing duties to counteract the trade distorting effect provoked by what is considered an unlawful subsidisation. As for dumping practices, the ADA provides exclusively for the unilateral procedure. See ASCM Part V and Part X, ADA Part I.

57 Infra $§ 2.3$.

58 On the promotion of renewables and WTO subsidy law, see Rubini, L., "Ain't wasting time no more: subsidies for renewable energy, the SCM Agreement, policy space and law reform", Journal of International Economic Law, vol. 15 ed. 2, 2012, 527-579, Rubini, L., "The Subsidization of Renewable Energy in the WTO: Issues and Perspectives", 3 August 2011, available online at $<$ ssrn.com/abstract=1904267> (accessed 5 May 2014) and Bigdeli, S. Z., supra nt. 47. For review of the ASCM discipline, see Horlick, G. N., Clarke, P. A., "WTO Subsidies discipline during and after the crisis", Journal of International Economic Law 13(3), 2010, 859-874.

59 Measures granted by WTO Members are classified as $i$ ) incentives to promote the invention of climatefriendly technologies and ii) incentives to encourage the deployment of such technologies. The latter are further distinguished between $i$ ) fiscal measures, $i$ ) price support measures or iii) investment support measures. See, WTO/UNEP Report on Trade and Climate Change, available online at 114 <www.wto.org/english/res_e/booksp_e/trade_climate_change_e.pdf> (accessed 15 February 2014). See also Vergano, P. R., Laterza, E. C., "Subsidies to renewable energy sources and international trade", Global Trade and Customs Journal, vol. 5, ed. 6, 2010, 224-227.

60 Only subsidies defined as 'specific' within the meaning of Article 2 ASCM are actionable for WTO purposes.

61 Pursuant to Article 3 ASCM prohibited subsidies are always assumed to be specific and harmful for international trade and hence cannot be maintained by WTO Members. All the other types of specific subsidies are considered "actionable" under the meaning of Articles 5 and 6 . This means that they might be subject to challenge only if they are demonstrated to cause an adverse effect to the interests of other WTO Members. See, among others, Lowenfeld, A. F., International Economic Law, Oxford University Press, Oxford, 2008, 238 et seq., Van den Bossche, P., The Law and Policy of World Trade 
the outset, the ASCM included a provisional waiver for subsidies granted in pursuance of certain specific goals, among which was the 'adaptation of existing facilities to new environmental requirements' ${ }^{62}$ This exception, however, lapsed after five years in 1999, ${ }^{63}$ leaving prohibited and actionable categories as the only two possibilities to define a specific subsidy for WTO purposes. ${ }^{64}$ It results that, at the moment, uncertainty remains mainly with regard to the compatibility of government subsidisation programs for renewable energies with the "specificity" and "adverse effect" tests foreseen in the ASCM. ${ }^{65}$ As further illustrated below, the DSB jurisprudence might be of great help in clarifying to what extent the ASCM rules constrain the WTO Members' policy space when it comes to incentivising the production of energy through renewable sources. ${ }^{66}$

\section{Renewable Energy Generation as a Trigger For International Disputes}

The utilisation of renewable energy sources for the production of electricity may lead to disputes involving the impairment of private interests to the benefit of the public interest. Such disputes are settled by domestic authorities and typically do not involve any transnational environmental harm (although this possibility cannot be ruled out a priori). This is confirmed by the slim record of cases regarding energy generation from renewable sources handled either by the international judiciary or by international extra-judicial means. A first case surged when a Chamber of the European Court of Human Rights (ECtHR) decided on the admissibility of an application concerning the operation of wind turbines and their alleged interference with the enjoyment of the right to private and family life by Swedish nationals. ${ }^{67}$

Another one has been recently handled by the Aarhus Compliance Committee. On the basis of a communication lodged by an Irish citizen, this body has recommended the EU to better comply with the Aarhus Convention in relation to the implementation of certain

Organization, Cambridge University Press, Cambridge, 2005, 561 et seq., Picone, P., Ligustro, A., Diritto dell'Organizzazione Mondiale del Commercio, supra nt. 49, 241 et seq.

${ }^{62}$ Article 8.2(c) ASCM.

63 Non-actionable subsidies were conceived, from the outset, as provisional. Pursuant to Article 31 ASCM they could have been extended by the Committee on Subsidies and Countervailing Measures with the consent of all the Parties.

64 It is argued that a legal shelter for certain types of subsidies could be re-introduced in the ASCM. See Horlick, G.N., Clarke, P. A., supra nt. 58., 870 et seq. On legal shelters specifically targeted at renewable energy subsidies, see Horlick, G. N., "The WTO and climate change incentives", in: Cottier, T., Nartova, O., Bigdeli, S. Z., supra nt. 47, 193.

65 In this sense, see Rubini, L., (2012), supra nt. 58, 544-545. On the specificity and the adverse effect of renewable energy subsidies, see Bigdeli, S. Z., supra nt. 47, 179-185. It has been argued that many proposals for energy subsidies are made with no knowledge of the ASCM rules or they rely on Article XX of the GATT 1994 which is by most considered not applicable to the ASCM. See Horlick, G. N., "The WTO and climate change incentives", in: Cottier, T., Nartova, O., Bigdeli, S. Z., supra nt. 47, 192.

66 Rubini, L., Written submission of Non-Party Amicus Curiae before the WTO Appellate Body, 12 March 2013, para. 99, available online at <birmingham.ac.uk/Documents/collegeartslaw/law/iel/rubini-2013-amicus-curiae.pdf $>$ (accessed 05 May 2014).

67 ECtHR, 26 February 2008, Fägerskiöld v. Sweden, Decision as to the admissibility of appl. No. 37664/04, Application No. 37664/04, available online at $<$ hudoc.echr.coe.int/sites/eng/pages/search.aspx?i=001-85411> (accessed 21 February 2014). 
aspects of its legislation on the use of renewable energy resources. ${ }^{68}$ However, technologies exploiting renewable energy sources like photovoltaic panels and wind turbines, as objects of international trade, are also capable of triggering inter-State disputes. In this regard, tensions concerning the market access of renewable energyrelated products have already resulted in the significant utilization of trade defence instruments, both anti-dumping and countervailing duties, by the EU and the US against solar panels imported from China. Furthermore, the allegedly protectionist provisions of 'local content requirements' (LCRs) in a Canadian regional policy on clean energy production have led to a long-awaited WTO decision which touches upon the very delicate relationship between WTO subsidy rules and climate change incentives. ${ }^{69}$ This section attempts to analyse these disputes in the light of the relationship between renewable energy and sustainable development as a principle of international law.

\section{II.1. Renewable Energy Generation and the Protection of Human Rights: a comment on the Fägerskiöld v. Sweden ECHR case}

The facts underpinning the commencement of Fägerskiöld v. Sweden before the ECtHR concern the granting of construction permits for three wind turbines neighbouring the applicants' property in the municipality of Ödeshög. The property, in particular, was bought as a second home and used for recreational purposes ${ }^{70}$ When the third turbine was erected in 1998 the applicants publicly denounced the disturbance caused by the noise and the light effects produced by the wind power plant. In front of the ECtHR, they retained that the operation of these turbines prevented them from fully enjoying some rights protected under the 1950 European Charter of Human Rights as the right to respect of private and family life (Article 8), the right to property (Article 1, Protocol N. 1) and the right to effective domestic remedies (Article 13) ${ }^{71}$ In sum, when decided on the admissibility of the case, the Court dismissed all claims as ill-founded.

While easily finding that the applicants had not in fact exhausted the available domestic remedies, the Court reflected on the possible admissibility on the basis of the other two alleged violations. As concerns Article 8, while admitting the absence from the Convention of any right to 'a clean and quiet environment', ${ }^{72}$ the Court also reaffirmed

68 Aarhus MOP, October 2012, Compliance Committee, 'Findings and recommendations with regard to communication ACCC/C/2010/54 concerning compliance by the European Union', $\mathrm{ECE} / \mathrm{MP} / \mathrm{PP} / \mathrm{C} .1 / 2012 / 12$.

69 WTO Panel Report, 19 December 2012, Canada - Certain Measures Affecting the Renewable Energy Generation Sector, Canada - Measures Relating to the Feed-in Tariff Program, WT/DS412/AB/R, WT/DS412/R, WTO Appellate Body Report, 6 May 2013, Canada - Certain Measures Affecting the Renewable Energy Generation Sector, Canada - Measures Relating to the Feed-in Tariff Program, WT/DS426/AB/R, WT/DS426/R.

70 By recalling Demades $v$. Turkey, application No. 16219/90, judgment of 31 July 2003, paras. 31-34, the Court removed all doubt on secondary homes as falling within its interpretation of 'home' ex Art.8, para. 1. See Fägerskiöld v. Sweden, supra nt. 67, 14.

71 European Convention on Human Rights and Fundamental Freedoms, adopted 4 November 1950, into force 3 September 1953 and Protocol to the Convention on Human Rights and Fundamental Freedoms, adopted 20 March 1952, into force 18 May 1954, both ratified by 47 Council of Europe's Member States. Both texts available online at <www.echr.coe.int/Documents/Convention_ENG.pdf > (accessed 8 March 2014).

72 In relation to the positive obligation to protect ECHR rights, the Court has consequently referred to the jouissance d'un environnement sain et protégé (enjoyment of a healthy and protected environment), see 
that an individual may be affected by noise and pollution likely to cause an infringement of the right to private and family life. ${ }^{73}$ After recalling its previous Article 8 environmental jurisprudence ${ }^{74}$ the Court focused on the severity test, according to which in order to raise an issue under the provision at stake 'interference must directly affect the applicants' home, private and family life and the effects of the environmental pollution must attain a certain minimum level of severity', ${ }^{75}$ two criteria satisfied by the circumstances of all Article 8 cases. In the case at hand, the Court admitted that the combined nuisance caused by the turbine noise and blades rotation was direct; however, after an assessment of the evidence reproduced by the applicant carried out in light of i) international noise standards ii) requirements set under the Swedish legislation and iii) a comparison with the noise levels reached in other Article 8 cases, the Court determined that the nuisance did not amount to 'severe environmental pollution'. ${ }^{76}$

Similarly, the allegations under Article 1 of Protocol 1 were also ill-founded in the Court's view. In relation to this provision, the Chamber had to decide on the proportionality of the alleged violation of the right to property and the general interest being pursued through the operation of the wind power plant. In this regard, it verified the lawfulness of the building permits issued for the construction of the third (particularly controversial) turbine against Swedish legislation and found no infringement, before passing to the test of the general interest attached to electricity generation and finding it to be superior to the negative impacts suffered by the applicants. Some aspects of the reasoning used by the Court to decide on the admissibility of Fägerskiöld v. Sweden are interesting as they repeatedly touched upon the relationship between renewable energy and the principle of sustainable development (crucial to understand in order to develop any international obligation on renewable energy) ${ }^{77}$ To a certain extent, for instance, the Court seemed to embrace the allegation of the Swedish Government affirming that the necessity test ex Article 8, paragraph 2 is a priori satisfied, in relation to wind power plants, thanks to the peculiarities of this energy source and its related technologies (they

ECtHR, Tatăr and others v Romania, Judgment of 27 January 2009, Application No. 67021/2001, para. 107, and ECtHR, Di Sarno and others v. Italy, Judgment of 10 January 2010, Application No. 30765/2008, para. 110.

73 Fägerskiöld v. Sweden, supra nt. 167, 14. 'The Court has constantly affirmed that the positive obligation to undertake adequate measures in order to protect the right under Art. 8 primarily involves the adoption of a legal and administrative framework ensuring the effective prevention of environmental and human health damages.' See Tatăr and others $v$ Romania, supra nt. 72, para. 88 and Di Sarno and others v. Italy, supra nt. 72, para. 108. On this case law, Ferrara, M., "La sentenza Di Sarno e altri c. Italia: un'ulteriore passo avanti della Corte di Strasburgo nell'affermazione di obblighi di protezione dell'ambiente", $L a$ Comunità internazionale, vol. 68, ed. 1, 2013, 161-177.

74 Ushered in by ECtHR, López Ostra v. Spain, Judgment, 9 December 1994, Application No. 16798/90, [1994] Series A, No. 303-C. For related case-law, see e.g. Dejeant-Pons, M., "Le droit de l'homme à l'environnement das le cadre du Conseil de l'Europe", Revue Trimestrielle des Droits de l'Homme, 60/2004, 861-888 and Pedersen, O., "European Environmental Human Rights and Environmental Rights: A Long Time Coming?", Georgetown International Environmental Law Review, vol. 21, ed.1, 2008, 83-93.

75 Fägerskiöld v. Sweden, supra nt. 67, 15.

76 Id., 16.

77 Briefly on this decision, Tegner Anker, H., Egelund Olsen, B., Rønne, A., "Wind Energy and the Law: a Comparative Analysis", Journal of Energy \& Natural Resources Law, vol. 27, 2009, 145 and Shelton, D., "Resolving Conflicts Between Human Rights and Environmental Protection", in: De Wet, E. and Jure, V., eds., Hierarchy In International Law, Oxford University Press, Oxford, 2012, 229. 
being environmentally friendly and contributing to the sustainable development of the society).

It must be admitted, however, that this faith in the utilisation of a renewable energy technology would not have appeared as such had the Court found that the adverse effects of the debated developments were actually reaching the degree of severity registered in other cases. In fact, the task of the Court is not to pronounce itself on the desirability of the activities likely to cause nuisance but rather to assess their compatibility with the rights protected by the Charter as, in certain circumstances, their effects may be detrimental to the enjoyment of those same rights. In relation to the right to property under Article 1 of Protocol N.1 affirming that 'no one shall be deprived of its possession except in the public interest and subject to the conditions provided by law and the general principles of international law' the Court went beyond the only apparently unconditioned support to renewable energy generation. In fact, when assessing the negative impact of the wind turbines on the enjoyment of the right to property against the general interest pursued through their operation, the Court found the interference to be proportionate and explicitly attached great relevance to the 'positive environmental consequences of wind power for the community as a whole'.$^{78}$

The implications of this decision are significant, even though not much has been added to the solid ECtHR environmental jurisprudence. In particular, the Court acknowledged the existence of a direct link between renewable energy generation inherently implicating a less likely degree of interference with the rights protected under the Convention - and sustainable development, the latter being characterized both as a public and general interest, on the basis of which States can legitimately authorize activities interfering with the use of property.

\section{II.2. Renewable Energy Generation and Procedural Environmental Rights: the Aarhus Compliance Committee on the Compatibility of Directive 28/2009/EC on Renewable Energy with Public Participation and Information Requirements}

Another case concerning renewable energy generation (in a broader context) has been handled by the compliance mechanism provided for under the Aarhus Convention. ${ }^{79}$ The issue, brought to the attention of the Compliance Committee ${ }^{80}$ by an Irish citizen,

78 Fägerskiöld v. Sweden, supra nt. 67, 19, stressing that 'the wind turbine at issue in the present case is capable of producing enough energy to heat between 40 and 50 private households over one-year period, which is beneficial both for the environment and for society'.

79 Convention on Access to Information, Public Participation in Decision-making and Access to Justice in Environmental Matters (Aarhus, Denmark), adopted 25 June 1998, into force 30 October 2001 (as of 2 April 2013 it has 47 Contracting Parties) available online at <unece.org/env/pp/treatytext.html> (accessed 21 February 2014).

80 Instituted by MOP1 (Lucca, Italy, 21-23 October 2002) pursuant to Aarhus Convention Article 15 through the adoption of Decision 1/7, on 'Review of compliance', in ECE/MP.PP/2/Add.8, of 2 April 2004 , available online

<unece.org/fileadmin/DAM/env/pp/documents/mop1/ece.mp.pp.2.add.8.e.pdf> (accessed 21 February 2014), the Compliance Committee is one of the most active non-compliance mechanisms provided under multilateral environmental agreements (MEAs). See Pitea, C., "Procedures and Mechanisms for Review of Compliance under the 1998 Aarhus Convention on Access to Information, Public Participation and Access to Justice in Environmental Matters" in Treves, T. et al., eds., Non- 
regarded the alleged failure to comply with a series of obligations of the Convention on part of the $\mathrm{EU}^{81}$ in relation to the Irish Renewable Energy Feed-In Tariff Program (REFIT I), supported by the European Commission by means of direct funding and State aid approval, and in relation to the Ireland's National Renewable Energy Action Plan (NREAP), a policy instrument required to Member States ex Article 4, paragraph 1 of directive 2009/28/EC. ${ }^{82}$ According to the complainant, EU institutions failed, inter alia, in monitoring the 'implementation of EU law related to the Convention' by Ireland, with respect to the preparation and subsequent communication of its NREAP. ${ }^{83}$ The Compliance Committee ultimately decided to centre its final evaluation around this issue, dismissing other allegations concerning State aid as well as those on the implementation of EU environmental legislation. ${ }^{84}$ Specifically, the Committee found Ireland's NREAP to fall into the definition of plan and program requiring public participation as set under Article 7 of the Aarhus Convention, since it had established 'the framework for activities by which Ireland aims to enhance the use of renewable energy in order to reduce greenhouse gas emissions' ${ }^{85}$ However, giving that authorities responsible for the identification of the concerned public were the Irish ones and Ireland is not a Party to the Convention, the Committee was unable to reach a conclusion on 'direct' compliance with Article 7. Accordingly, it turned its attention to the requisites for public participation singled out by directive 2009/28/EC because, as stated in the findings, while the integration of such requisite was a choice of the EU, 'it is the task of the Committee to examine whether the Party concerned has indeed properly implemented Article 7 of the Convention'. ${ }^{86}$ In the light of this, the Committee analysed the obligations under Article 4 of the directive ${ }^{87}$ and held them as of 'very general nature',

Compliance Procedures and Mechanisms and the Effectiveness of International Environmental Agreements, Asser Press, Den Haag, 2009, 221-250.

81 Unlike Ireland, the EU is an Aarhus Contracting Party. See Decision 2005/370/EC of the Council of the European Union, of 17 February 2005, on the conclusion, on behalf of the European Community, of the Convention on access to information, public participation in decision-making and access to justice in environmental matters, in $O J$ L-124 of 17 May 2005, 1-3.

82 Directive 2009/28/EC of the European Parliament and of the Council of 23 April 2009 on the promotion of the use of energy from renewable sources and amending and subsequently repealing Directives 2001/77/EC and 2003/30/EC, in OJ L-140 of 5 June 2009, 16-62.

83 Aarhus MOP, October 2012, Compliance Committee, ECE/MP/PP/C.1/2012/12, supra nt. 68, para. 3,2 .

84 Id., paras. 73-74, 12. In particular, the communication challenged the missed submission of the Irish NREAP to the strategic environmental assessment procedure set for plans and programs by the Directive 2001/42/EC of the European Parliament and of the Council of 27 June 2001 (commonly known as 'SEA Directive') and the violation of Directive 2003/35/EC (the so-called 'EIA Directive') in relation to an interconnector project (under REFIT I) in turn funded on the basis of Regulation (EC) No $663 / 2009$ of the European Parliament and the Council of 13 July 2009 establishing a program to aid economic recovery by granting Community financial assistance to projects in the field of energy (then labelled as the 'European Energy Program for Recovery' or EEPR).

85 Aarhus MOP, October 2012, Compliance Committee, ECE/MP/PP/C.1/2012/12, supra nt. 68, para. $75,12$.

86 Id., para. $77,13$.

87 Having regard also to the Directive's Preamble (recital 90) and further guidance provided by the Commission Decision of 30 June 2009 establishing a template for National Renewable Energy Action Plans under Directive 2009/08/EC (required by Art. 4, para. 2). 
contemplating 'minimum requirements' for Member States not in line with those concerning public participation established by Article 7 of the Convention. ${ }^{88}$

In this regard, it specified that measures consistent with the latter provision would have required Member States to report on the public participation arrangements made for NREAP preparation, on how information was made available and, most importantly, would have been set within a regulatory framework incorporating the requirements under Article 6, paragraph 3,4 and 8 of the Convention, ensuring the availability of adequate time-frames for informing the public providing the conditions for effective participation. ${ }^{89}$ On this point the Committee observed that consultation with the public in the case a quo were carried out in a limited time-span and that it would not have been so had the EU included standards in line with Article $7 .^{90}$ Finally, having ascertained EU failure in ensuring implementation of this provision ('by way of its monitoring responsibility'), the Committee recommends ending non-compliance. ${ }^{91}$

Although only incidentally related to renewable energy, the Committee's findings have interesting EU and international law implications. On the one hand, they deal with the consistency of EU secondary legislation with agreements ratified by the Union and with the implementation of their principles by Member States not having ratified them in the first place but contextually bound by virtue of Article 216, paragraph 2 TFEU. On the other hand, the findings should be taken into account for developing any international law instrument entailing procedural environmental requirements for renewable energy plans and project.

\section{II.3. Renewable Energy Generation and Trade Defence Instruments: A Comment On EU Unilateral Trade Measures Against Chinese Solar Panels}

Due to the growing economic relevance of trade in renewable energy technologies, the application of countervailing or antidumping duties in this field is becoming an increasingly common practice. In an effort of safeguarding national producers from unfair competition, WTO Members have reacted very quickly when alleged anticompetitive practices enacted by third countries and manufacturers were threatening their national industries operating in the same field. ${ }^{92}$ At the moment, China is by far the larger exporter of solar photovoltaic (PV) technologies and its trade balance vis-à-vis the US and the EU has grown exponentially in the last few years. ${ }^{93}$ Not surprisingly then,

88 Aarhus MOP, October 2012, Compliance Committee, ECE/MP/PP/C.1/2012/12, supra nt. 68, para. 79, 13.

89 Id., para. 80, 13. The Committee went further by declaring that the Commission ('Party concerned') did not reproduce evidence concerning any control on the Irish NREAP in the light of Aarhus Convention's Article 7 (para. 81).

90 Id., paras. 82-83. The Committee recalled its findings on communication ACCC/C/2006/16 (Lithuania), ECE/MP.PP/2008/5 Add. 6, para. 69: Two weeks are not reasonable for the public 'to prepare and participate effectively'.

91 Id., paras. 95 and 98 . The Committee refers to the monitoring power of the Commission and to the judicial control of the European Court of Justice. Short of suggesting means for correction (i.e. amending Directive 2009/28/EC) the Committee only re-states the causes of non-compliance.

92 Supra nt. 48.

93 Latest UN statistics (United Nations Commodity Trade Statistics Database - UN Comtrade) show a strong imbalance in favour of China in the international trade of photovoltaic modules and 
both the US and the EU have recently questioned the legality of subsidies and dumping practices applied by the Chinese government and Chinese manufacturers to their export of solar PV and related products. On the basis of investigations carried out by the US Department of Commerce (DoC) in 2012, the U.S. International Trade Administration (ITA) has already issued its final determination finding that solar PV imported from China to the US had benefited from various forms of illegal subsidies and dumping practices. ${ }^{94}$ Consequently, the US is now applying additional tariffs ranging from $24 \%$ to $36 \%$ on most of the solar PV cells originating from China. ${ }^{95}$ Similarly, the EU has initiated four parallel investigations aimed at verifying the existence of export subsidies and dumping practices on certain solar PV products imported from China. ${ }^{96}$ One of these has already led to the imposition by the European Commission (EC) of a provisional (six-months) anti-dumping duty on Chinese solar PV amounting to an average $47 \%{ }^{97}$ calculated as the minimum threshold in order to counteract the negative effect of the dumping practice. ${ }^{98}$

The concerns of States and industrial sectors feeling threatened by unfair competition practices are justifiable as one thinks that a large amount of imports of low-cost renewable energy generators from third countries can delay, if not prevent, the development of a national industry, with a series of implications in terms of tax collection, jobs losses and self-sufficiency. ${ }^{99}$ However, the imposition of further duties on renewable energy goods may raise concerns if seen from other perspectives. Trade

components. In 2011 China exports of photosensitive semiconductor devices (HS 854140) amounted to almost 28 billion USD against the 2 billion exports of the US. According to the European Commission the EU is China's main export market for solar panels, accounting for around $80 \%$ of all Chinese export sales. See MEMO/13/497, 'EU imposes provisional anti-dumping duties on Chinese solar panels', of 4 June. 2013, available online at <europa.eu/rapid/press-release_IP-13-501_en.htm> (accessed 2 February 2014).

94 See ITA, 'Commerce Finds Dumping and Subsidization of Crystalline Silicon Photovoltaic Cells, Whether or Not Assembled into Modules from the People's Republic of China', available online at <ia.ita.doc.gov/download/factsheets/factsheet_prc-solar-cells-ad-cvd-finals-20121010.pdf> (accessed 2 February 2014).

95 See, ITA press release available online at <trade.gov/press/press-releases/2012/final-determinationsin-the-antidumping-duty-and-countervailing-duty-investigations-of-imports-of-solar-cells-from-china101012.asp > (accessed 2 February 2014).

96 European Commission, 'Notice of initiation of an anti-dumping proceeding concerning imports of crystalline silicon photovoltaic modules and key components (i.e. cells and wafers) originating in the People's Republic of China', OJ C 269/5, 6.9.2012. European Commission, 'Notice of initiation of an anti-subsidy proceeding concerning imports of crystalline silicon photovoltaic modules and key components (i.e. cells and wafers) originating in the People's Republic of China', OJ C 340/13, of 8 November 2012. European Commission, 'Notice of initiation of an anti-dumping proceeding concerning imports of solar glass originating in the People's Republic of China', OJ C 58/6, of 28 February 2013. European Commission, 'Notice of initiation of an anti-subsidy proceeding concerning imports of solar glass originating in the People's Republic of China', OJ C 122/24, of 27 April 2013.

97 Commission Regulation (EU) No 513/2013 of 4 June 2013 'imposing a provisional anti-dumping duty on imports of crystalline silicon photovoltaic modules and key components (i.e. cells and wafers) originating in or consigned from the People's Republic of China and amending Regulation (EU) No $182 / 2013$ making these imports originating in or consigned from the People's Republic of China subject to registration', OJ L 152/5, of 5 June 2013.

98 The other investigations are expected to reach provisional or final conclusions by end of 2013.

99 All EC anti-subsidy and anti-dumping investigations were initiated following a complaint lodged by EU Pro SUN on behalf of EU companies representing more than $25 \%$ of the total Union production of the technology at stake. 
defence instruments to renewable energy technologies, for instance, seem to run counter to the aforementioned DDA objective of market opening for environmental products. ${ }^{100}$ Furthermore, the imposition of additional tariffs (either anti-dumping or countervailing measures) to the import of solar PV from China may not be in the interest of the whole industry operating in the upstream and downstream markets. Significantly, right after the commencement of the investigations against the allegedly WTO-inconsistent practice of China, many EU and US-based companies started to fear the potentially negative effects likely to be caused by the imposition of anti-dumping and countervailing measures on solar PV for the global solar value chain. ${ }^{101}$ Finally, from the consumer's perspective, it is easy to argue that countervailing and anti-dumping duties, whether legitimate or not, have the immediate effect of increasing the costs of technologies needed for the production of clean energy (i.e. the cost of solar installations), ultimately increasing the average price of energy from renewable sources, to the detriment of end-users.

Safeguarding the interests of subjects other than national industries is certainly not the main objective of trade defence measures. WTO relevant agreements (ADA and ASCM) do not require parties to take non-trade interests into consideration when applying antidumping and anti-subsidy duties. ${ }^{102}$ Conversely, however, the EU system envisages specific rules for this purpose. Before applying any trade defence measure, in fact, the EC must undertake the so-called "Union Interest test" by which trade concerns of EU companies damaged by the alleged unlawful behaviour of third Parties are weighted against the interest of the society as a whole. ${ }^{103}$ The Union Interest test is based on "an appreciation of all the various interests involved", including, in the case of Chinese solar panels, "those of the Union industry, companies in the upstream and downstream markets of the PV sector, importers, users and consumers of the product concerned". ${ }^{104}$ For this reason one can consider the test as offering an ideal platform for discussing sustainability goals in the context of trade defence measures. However, in deciding on provisional anti-dumping duties against Chinese exporters, the EC seems to have opted for a narrow interpretation of the test so to exclude the possibility for it to encompass wider sustainability and environmental concerns.

In assessing the harm likely to be caused by the imposition of an anti-dumping duty, the EC focuses greatly on the impact of an increased pricing for undertakings operating in the upstream and downstream markets and for the end-users. ${ }^{105}$ Only under the heading "other arguments" the thorny issue of the contrast between the imposition of

100 The cases addressed here might be seen as an indicator of the reasons behind the failure of EGS negotiations.

101 These companies are currently grouped into two coalitions: Alliance for Affordable Solar Energy (AFASE) in the EU and the Coalition for Affordable Renewable Energy (CASE) in the US.

102 The three-fold requirement to be fulfilled for imposing anti-dumping duties and countervailing measures (GATT Article VI) consists in proving the existence of $i$ ) a dumping practice (or a subsidy), ii) an injury to the domestic market and iii) a causal link between the two.

103 The legal basis of the test rests in Article 21 of Council Regulation (EC) n. 1225/2009 of 30 November 2009 'on protection against dumped imports from countries not members of the European Community', OJ L 343/51, 22 Dec. 2009 and Article 31 of Council Regulation (EC) n. 597/2009 of 11 June 2009 'on protection against subsidised imports from countries not members of the European Community', OJ L 188/93, 18 Jul. 2009. See, Wellhausen, M., "The Community Interest Test in Antidumping Proceedings of the European Union", American University International Law Review, 2001, vol. 16, ed. 4, 1027-1082.

104 Commission Regulation (EU) No 513/2013, supra nt. 97, para. 225.

105 Id., paras. 235-254. 
anti-dumping duties and the renewable energy goals of the 2020 Agenda is briefly addressed. ${ }^{106}$ Significantly, in deciding on the imposition of trade defence instruments, the EC quickly dismisses this important point by stating that "the 2020 goals do not depend on the solar energy exclusively. Equally important are other green energies such as: wind, biomass, hydro etc. Since no particular percentage is attributed to the solar energy for the 2020 goals, a slightly lower number of PV installations is not expected to raise the overall cost of the 2020 Agenda" adding that "the price of solar panels is only one of many factors, which are vital for the development of the PV industry in Europe". ${ }^{107}$

In light of the above, it might be tempting to argue that the economic importance of the case and the political will to react quickly to the threat posed by cheap import of solar technologies have led the EC to refrain from investigating further on the relationship between trade remedies and renewable energy policies. ${ }^{108}$ Forthcoming decisions on antisubsidies and anti-dumping will certainly be of great help in confirming or discarding this interpretative position.

\section{II.4. Renewable Energy Generation and WTO Subsidy Rules: The WTO Consistency of Financial Assistance Programs and their Local Content Requirements in the Canada - FIT Program dispute}

Compatibility concerns with regard to WTO rules and renewables have been mounting also in the context of domestic climate change incentives for the production of clean energy. ${ }^{109}$ The first, and so far the only decision by a WTO Panel and the Appellate Body (AB) regarding the consistency of financial assistance programs for renewable energy generation was reached in relation to the 'Ontario Feed-in Tariff Program (FIT Program)' at the request of Japan and the EU. ${ }^{110}$ Similarly to other government assistance schemes, the Canadian Program is a comprehensive guaranteed pricing structure aiming at increasing the production of electricity from certain renewable energy sources with the two-tier goal of improving air quality and diminishing the dependence on coal-fired energy generation ${ }^{111}$. In order to boost investments in this otherwise non-profitable

106 Besides increasing to $20 \%$ the quota of energy consumption produced from renewable resources by 2020, the 2008 EU Energy and Climate Package (comprising inter alia Directive 28/2009/EC on renewable energy), pursues other two goals: reducing GHG emissions by 20\% from 1990 levels and raising by $20 \%$ the overall EU's energy efficiency. Said goals are core to the 2020 Agenda. See European Commission, "Europe 2020. A strategy for smart, sustainable and inclusive growth", COM(2010) 2020 final, 3 March 2010, 11.

107 Commission Regulation (EU) No 513/2013, supra nt. 97, para. 258.

108 The Commission showed particular concern for the disappearance of the Union industry and for the price consequences of having one single supplier (China) of solar PV modules. Id., para. 253.

109 Besides the dispute on the Ontario FIT Program, other requests for consultations on WTO Members' feed-in tariff programs have been recently issues to the DSB. See, DS419, 'China - Measures concerning wind power equipment', DS452, 'European Union and certain Member States - Certain Measures Affecting the Renewable Energy Generation Sector', DS456, 'India - Certain Measures Relating to Solar Cells and Solar Modules'.

110 Supra nt. 69.

111 See Ontario's Ministry of Energy, FIT and MicroFIT Program, available online at <energy.gov.on.ca/ en/fit-and-microfit-program> (accessed 2 February 2014). 
business, the Ontario FIT Program offers fixed and favourable long-term contracts for the purchase of electricity. ${ }^{112}$ One of the requirements for eligibility of operators to the FIT Program and the main target of complaints from WTO Members is the inclusion in each project of a "minimum amount of goods and services that come from Ontario". ${ }^{113}$ This requirement entailing a local content obligation (LCR) is explicitly adopted for the purpose of enabling "new green industries through new investments and job creation". ${ }^{114}$ Japan and the EU asked the Panel to rule on the legality of the FIT Program's LCR with both the general non-discrimination clause provided for in GATT Article III: $4^{115}$ and the subsidy discipline of the ASCM.

As for the first claim, the Panel and then the $A B$ had no difficulties in demonstrating the clear discriminatory character of the LCR and that no exception could be invoked. ${ }^{116}$ In rebutting Canada's claim according to which the FIT Program would constitute a form of government procurement, as such exempted from Article III applicability, the Panel noticed that the commercial character of the transaction in the FIT program (the energy ultimately being sold to consumers) prevented the applicability of the exception. The AB reversed the Panel's reasoning - but not the final decision - by highlighting that the government procurement exception of GATT Article III:8 could not be invoked insofar as the product being allegedly procured (electricity) was not the same product being allegedly discriminated because of its origin (generation equipment). ${ }^{117}$ In distinguishing between the two different products, the $A B$ probably aimed at clearing the field from the misconception that energy-related products are to be subjected to a more lenient WTO discipline merely because of their specific function. In the end, as requested by the complainants, the LCR was declared inconsistent with GATT Article III and also with Article 2.1 of the TRIMs Agreement. ${ }^{118}$

Secondly, the Panel and the AB were asked to rule on the consistency of the LCR with the ASCM. The complainants alleged that the FIT contracts constituted a prohibited subsidy within the meaning of ASCM Article 3.1(b) because the granting of a favourable treatment was contingent upon the use of domestic over imported goods. ${ }^{119}$ In these

112 See WT/DS412/R, WT/DS426/R, supra nt. 69, para. 7.65.

113 See, 'FIT Program Overview', Version 2.1, Ontario Power Authority, para. 3.1, available online at: $<$ fit.powerauthority.on.ca/sites/default/files/page/FIT_Program_Overview_Version_2.pdf $>$ (accessed 2 February 2014).

114 WT/DS412/R, WT/DS426/R, supra nt. 69, para. 7.65.

115 Mandating that "the products of the territory of any contracting party imported into the territory of any other contracting party shall be accorded treatment no less favourable than that accorded to like products of national origin in respect of all laws, regulations and requirements affecting their internal sale, offering for sale, purchase, transportation, distribution or use".

116 On this point, Canada contended that FIT contracts constituted "laws and requirements that govern the procurement of renewable electricity for the governmental purpose of securing supply for Ontario consumers from clean sources" and were thus covered by the provision of GATT Article III:8(a) exempting government procurement from the non-discrimination principle. WT/DS412/R, WT/DS426/R, supra nt. 69, para.7.88 et seq.

$117 \mathrm{WT} / \mathrm{DS} 412 / \mathrm{AB} / \mathrm{R}, \mathrm{WT} / \mathrm{DS} 426 / \mathrm{AB} / \mathrm{R}$, supra nt. 69, para. 5.79.

118 The claimants further asked the DSB to find the inconsistency of the FIT program with Article 2 of the Agreement on Trade Related Investment Measures (TRIMs Agreement). According to TRIMs Article 2.1, a measure constituting a TRIM within the meaning of Article 1, which is also inconsistent with GATT Article III:4, violates the TRIMs Agreement.

119 ASCM Article 3 distinguishes between prohibited and actionable subsidies. Subsidies contingent upon export and upon the use of domestic over imported goods (import substitution subsidies) fall within the "prohibited" category and cannot be maintained by WTO Members. 
circumstances, before turning to the analysis of the import substitution measure (the LCR, in the case at hand), it is necessary, to determine the existence of the subsidy itself. For WTO purposes a subsidy exists when a financial contribution is granted and a benefit is conferred. ${ }^{120}$ In the present dispute, both the Panel and the AB found that the FIT Program amounted to a financial contribution within the meaning of ASCM Article 1.1(a)(1). ${ }^{121}$ However, with regard to the benefit, the Panel was of the view that, in the specific context of the electricity market, government intervention is always necessary in order to safeguard a safe, reliable and long-term sustainable electricity supply. ${ }^{122}$

For this reason, the Panel concluded that a free marketplace for electricity could not exist. Hence, it was not possible to find an appropriate market benchmark to verify that the FIT contracts conferred a benefit within the meaning of ASCM Article 1.1(b). ${ }^{123}$ The reasoning of the $A B$ on the benefit partially departed from the Panel's. The $A B$ in fact refused to confirm the Panel's view that the relevant market for the determination of the benefit is the whole electricity market. Instead, it ruled that, taking the supply mix decided by the Ontario government as given, the relevant market against which a benchmark needs to be found to prove the conferral of a benefit is the specific market for wind and solar generated electricity shaped on the basis of the energy-supply mix determined by the government. ${ }^{124}$ Consequently, the benchmark for the comparison of the FIT Program fixed prices is to be found in each specific market. Eventually, however, neither the Panel nor the $\mathrm{AB}$ were in the position to identify an appropriate benchmark for comparison. Therefore the existence of a subsidy for ASCM purposes could not be ascertained.

The decision on the Ontario FIT Program has been the first in which the DSB addressed the delicate subject of subsidies and renewable technologies. If the decision with regard to the discriminatory nature of LCRs has not received any criticism, the reasoning of the Panel and the $A B$ with regard to the definition of the benefit has raised more perplexities. Indeed, some important divergences on how to define the existence of

120 See ASCM, Art. 1.

121 Although reaching the same conclusion with respect to the characterization of the financial contribution at issue as a "purchase of goods" under ASCM Article 1.1(a)(1), the AB reversed the Panel's finding that the categories for the characterization of a subsidy are mutually exclusive. See WT/DS412/AB/R, WT/DS426/AB/R, supra nt. 69, paras. 5.121-5.128. Interestingly, the litigants never questioned the existence of a "financial contribution" within the meaning of the ASCM. However, the possibility for a pricing requirement such as a FIT Program to amount to a financial contribution has been questioned in doctrine because it has been maintained that such a minimum price purchase requirement should be intended as a market regulation activity. See, Howse, R., "Climate Mitigation Subsidies and the WTO Legal Framework: a policy analysis", IISD Paper 2010, 12. Contrary to the concept of subsidy as defined in WTO Agreements, the ECJ has ruled that minimum price purchase requirements for renewable electricity cannot constitute "state aid" within the meaning of Article 87 TEC because it does not entail a transfer of State resources. See CJEU, Case C-379/98, PreussenElektra AG v. Schleswag AG, 13 March 2001, ECR I-02099, paras. 59-60.

122 According to the Panel, modern electricity systems "by their very nature, need to draw electricity from a range of diverse generation technologies that play different roles and have different costs of production and environmental impacts", see WT/DS412/R, WT/DS426/R, supra nt. 69, para. 7.320.

123 Id., para.7.312.

124 The $\mathrm{AB}$ considered that government intervention resulting in the creation of a market which would not otherwise exist does not impede treating the resulting price as "market price" for the purpose of the benefit analysis. WT/DS412/AB/R, WT/DS426/AB/R, supra nt. 69, para. 5.185. 
the benefit had already emerged among the Panel experts, with one of the adjudicators issuing a dissenting opinion on this specific point. ${ }^{125}$

In criticising the decision, the dissenting judge and some commentators pointed out that, by refusing to acknowledge that a benefit is conferred, the Panel first and the AB later erroneously mixed up two different analytical dimensions. It has been maintained that, by trying to justify the absence of the benefit through the impossibility of finding a benchmark within the Ontario energy market, the Panel had implicitly justified the existence of the subsidy already in the benefit analysis. This, being a preliminary stage of the overall evaluation, should only have been aimed at the investigation of potential trade distortion of the measure at stake. ${ }^{126}$ The justification of the subsidy at issue could have become relevant at a later stage, namely in the context of the determination of the specificity of the measure or its adverse effect. ${ }^{127}$ Instead, it has been argued, by confusing the two different dimensions the Panel and, to a lesser extent, the $A B$, have missed the opportunity to proceed to the next phases of the analysis in which policy objectives, such as energy supply reliability and environmental sustainability, could have been raised as a possible justification for the adverse economic effect generated by the subsidy. This could have led to a much clearer understanding of the possible recognition, within the WTO, of a legal shelter, or at least a greater level of tolerance, for those domestic measures specifically targeted to renewable energy objectives. ${ }^{128}$

Criticism aside, it should be noted that, in overturning the Panel's reasoning by recognizing the existence of different relevant markets for each specific generation technology, the $\mathrm{AB}$ has implicitly ascertained the peculiarity of renewable technologies for the production of clean energy. This, coupled with a clear stand on the impossibility for WTO Members to question the legitimacy of each government definition of the appropriate energy supply mix, might render it difficult in the future to challenge the legitimacy of domestic climate change financial schemes not containing LCRs. Finally, from a more pragmatic standpoint, it is difficult to imagine why, in the absence of a discriminatory LCR, a WTO Member should embark in a costly and politically sensitive WTO dispute to challenge another Member's feed-in tariff scheme. ${ }^{129}$ In any case, it is left to the upcoming DSB decisions to confirm or overturn the reasoning developed by the $\mathrm{AB}$ in the FIT Canada dispute. ${ }^{130}$

125 See WT/DS412/R, WTDS426/R, 'Dissenting Opinion of one Member of the Panel with respect to whether the challenged measures confer a benefit within the meaning of Article 1.1.(b) of the SCM Agreement', para. 9.1 et seq.

${ }^{126}$ As noted, "one thing is to find that there are sound economic and policy reasons for the government to step in and direct the economy, surely quite another to suggest that we should not call an out-of-themarket incentive as such, only because it is a good one". See L. Rubini, supra nt. 66, para. 57. The AB however disregarded this position by confirming that the Panel 'did not err in using Article 14 of the ASCM as a context to determine whether a benefit is conferred under Article 1.1(b)', WT/DS412/AB/R, WT/DS426/AB/R, supra nt. 69, paras. 5.163-5.165.

127 See, Rubini, L., supra nt. 66, para. 89.

128 Id., para. 96.

129 It has been argued that the Ontario FIT Program dispute has been perceived, in trade circles, as a 'mistake', somewhat altering the previous equilibrium. See, Rubini, L. (2012), supra nt. 58, 557.

130 Supra nt. 109. 


\section{Some Aspects of International Cooperation in The Field of Renewable Energy}

Despite the reticence on the definition of global quantified renewable energy targets, the absence of binding norms on renewable energy generation and the persistence of various factors leading to disputes, global cooperation in the field of renewable energy is gaining momentum. Starting with an overview on CDM renewable energy projects under the Kyoto Protocol, this section will then shift to the latest developments in renewable energy cooperation respectively triggered by the creation of the International Renewable Energy Agency and by the growing number of transnational private partnerships operating in the field of renewables.

\section{III.1. The Kyoto Protocol and CDM renewable energy projects}

It has often been highlighted how the utilization of renewable energy is a key to the achievement of sustainable development. This relationship should also inform the conduct of international cooperation. It has been observed in particular how increasing the share of renewable energy in the global energy mix, while maximising energy efficiency and guaranteeing universal access to energy services is a crucial tripartite challenge for the international community as a whole. ${ }^{131}$ Alternative sources of energy are one of the means to accelerate poverty reduction and cut the bulk of greenhouse gas (GHG) emissions responsible for anthropogenic global warming with the help of utilityscale renewable power projects and more flexible small-scale renewable energy systems. ${ }^{132}$ Therefore, unprecedented political, financial and technological cooperation is required at all levels to achieve the globally agreed targets on sustainable energy. Notwithstanding these pressing needs, international cooperation in the field of renewable

131 Supra $\S 1.1$. The International Energy Agency (IEA) however projects a challenging future for the three targets requiring more rigorous policies and stronger political engagement, although new deployment of energy-efficient technologies were announced in different countries and new targets were set (e.g. the US opted for new fuel-economy standards, the EU hopes to cut by $20 \%$ its energy demand no later than 2020 , Japan intends to reduce by $10 \%$ its energy consumption by 2030 while China plans to cut back by $16 \%$ its energy intensity before 2015). Notwithstanding commitments, the energy efficiency target will still not be achieved, according to the IEA estimations. Equally, the share of renewable energy in the world energy mix will still be small, though it has grown steadily (in 2010-2011 renewables provided for about $16.7 \%$ of global energy consumption). In this scenario, the EU advanced in reaching its goals: the portion of energy from alternative sources has increased constantly from $7.9 \%$ in 2004 to $12.7 \%$ in 2010 . As for energy poverty, IEA considers that future investments should be at least five times the level of 2009 (9 billion USD). Increasing financing will presumably not be easy due to the diminishing political will of industrialised countries struggling with growing national debts. See, OECD/IEA, REPORT: 'World Energy Outlook 2012', Renewable Energy Policy Network for the 21st Century, 'Renewables 2012. Global Status Report' and European Commission, COM, 175, 2013, 'Renewable Energy Progress Report' of 27 March 2013.

132 Fossil fuels, however, keep on constituting a relevant portion of the world energy mix. It is impossible and for many reasons preposterous to renounce the use of less polluting traditional fuels (i.e. natural gas), which in the long run may be an excellent fuel for a transition from traditional sources to the renewable ones. The importance of natural gas was indeed recognised in the Bonn Agreements on the implementation of the Buenos Aires Plan of Action. See 'Report of the Conference of the Parties on the second part of its sixth session', held in Bonn from 16 to 27 July 2001, UN Doc. FCCC/CP/2001/5, of 25 September 2001, 52, available online at <unfccc.int/resource/docs/cop6secpart/05.pdf\#page $=36>$ (accessed 19 February 2014). 
energy is supported only by a few ad hoc international (mostly regional) norms and is conducted in the absence of an efficient institutional framework (which is in turn the product of a fragmented and dispersed global environmental governance). ${ }^{133}$

As briefly anticipated, one of the early instruments that up until now has been promoting joint action among States in the renewable energy sector is the 1997 Kyoto Protocol (KP) to the UNFCC. The KP can be regarded as the fruit of a large consensus on the seriousness and legitimacy of pressing climate change concerns and the inevitability of undertaking binding commitments in order to curb carbon dioxide $\left(\mathrm{CO}_{2}\right)$ emissions. When entered into force in 2005, after a difficult ratification path, the Protocol's so-called 'flexibility mechanisms' were finally set in motion. KP Article 3 mandates the general obligation of Annex I Parties ${ }^{134}$ to ensure that their aggregate anthropogenic GHG emissions do not exceed their assigned amounts, 'with a view to reducing their overall emissions of such gases by at least 5 per cent below 1990 levels in the commitment period 2008 to 2012'. Flexibility mechanisms were inserted in the Protocol in order to facilitate compliance with this provision and to enhance cooperation among all the UNFCCC Contracting Parties. Thus, Article 6 establishes a Joint Implementation (JI) system whereby Annex I Parties may transfer or acquire emission reduction units among themselves 'resulting from the projects aimed at reducing anthropogenic emissions by sources or enhancing anthropogenic removals by sinks of greenhouse gases in any sector of the economy'.

The second instrument provided by the KP is known as Clean Development Mechanism (CDM). From a technical standpoint, the CDM projects work the same way as the JI ones with the only exception that they are aimed at reducing emissions in the territory of developing countries (Non-Annex I Parties). The CDM pursues a twofold purpose: to assist developing countries 'in achieving sustainable development and in contributing to the ultimate objective of the Convention', while helping developed countries to respect their commitments under Article 3. Lastly, Article 17 enables an 'emission trading scheme' where extra carbon credits resulting from the implementation of the JI and the CDM projects can be traded. The provision actually created a new commodity and a new 'carbon market', as carbon dioxide accounts for $56.6 \%$ of all the anthropogenic GHGs. ${ }^{135}$

Notwithstanding the obligation under Article 3 and the provision of flexibility mechanisms, the Protocol does not require the adoption of renewable technologies as a mandatory method for cutting GHG emissions. ${ }^{136}$ However, during the negotiations following the adoption of the Protocol, several developing countries expressed the view that renewable energies should have been specifically given priority within activities

133 See supra $\S 1.2$ as well as Ivanova, M. H. and Esty, D. C., "Revitalizing Global Environmental Governance: A Function-Driven Approach", in: Ivanova, M. H., and Esty, D. C., eds., Global Environmental Governance: Options \& Opportunities, Yale School of Forestry \& Environmental Studies, 2002, 181-204.

134 Annex I Parties include industrialised OECD countries as of 1992 and States with economies in transition (Russia, the Baltic States, several Central and Eastern European countries). Non-Annex I Parties are those Contracting Parties recognised as 'developing' and 'least developed'.

135 Data available online at <ipcc.ch/publications_and_data/ar4/syr/en/figure-spm-3.html> (accessed 19 February 2014).

136 Indeed 'renewable forms of energy' are referred to only once by the Protocol, in Art. 2, a), iv. 
under the CDM. ${ }^{137}$ Thus far, this proposal remained only on paper. ${ }^{138}$ One of the reasons preventing its materialisation might have been that, at the time of the inception of the KP and for several years after its adoption, renewable energy technologies were not costefficient and such a condition could have created another stumbling block in the negotiations. ${ }^{139}$ However, the Protocol does not exclude investments in renewable energy either, but rather encourages them through its flexibility mechanisms designed to supplement the efforts undertaken by Annex I countries in achieving their national targets of emission reduction, particularly the CDM. In fact, $70 \%$ of the total amount of the CDM projects from the start of the crediting period until the end of 2012 are related to renewable energies. ${ }^{140}$

By the analysis of the data, it might appear that the mechanism is indeed serving well in expanding and providing support to renewable energies. Yet, the significance of renewables lessens if the weight of the Certified Emission Reductions (CERs) credits issued for different projects is taken into consideration. Project developers in fact opt mostly for ventures that capture and eliminate gases with high global warming potential, namely hydro-fluorocarbons (HFCs), per-fluorocarbons (PFCs), sulphur hexafluoride (SF) and nitrous oxide $\left(\mathrm{N}_{2} \mathrm{O}\right){ }^{141}$ These types of activities received $58 \%$ of CERs, twice the amount issued for the projects related to renewable energy $(25 \%) .{ }^{142}$ Ventures in the field of renewables usually create smaller volumes of emission reductions and sustain higher total investments per project.

A comparison between two large-scale CDM projects may highlight downsides encountered by clean energy initiatives. On the one hand, there is a Dutch investment company that financed a project for conversion of $\mathrm{SF}_{6}$ into alternative cover gas $\mathrm{SO}_{2}$ at a

137 See UNFCC/SBSTA, REPORT: 'Mechanisms pursuant to Articles 6, 12 and 17 of the Kyoto Protocol. Text for further negotiation on principles, modalities, rules and guidelines', 11 May 2000, UN Doc. FCCC/SB/2000/3, para.137 (79, f), available online at <unfccc.int/resource/docs/2000/sb/03.pdf> (accessed 5 May 2014).

138 While Contracting Parties agreed to elaborate principles, modalities, rules and guidelines on flexibility mechanisms (COP4, 1998), they initially failed to reach consensus (COP6, 2001). COP7 adopted a decision on 'Principles, nature and scope of the mechanisms pursuant to Articles 6, 12 and 17 of the Kyoto Protocol'. However, any measure advantaging renewable energy in the context of these mechanisms was left out. Modifications to the CMD have been scholarly invoked, too. While noting the CDM investment potential as Streck, C. and Lin, J., "Making Markets Work: A Review of CDM Performance and the Need for Reform", European Journal of International Law, vol. 19, ed. 2, 2008, 409442 , the doctrine also stressed the need for its reform. In this respect, see Voigt, C., "Is the Clean Development Mechanism Sustainable? Some Critical Aspects", Sustainable Development Law \& Policy, vol. 2, ed. 7, 2008, 15-21, Kneteman, C. and Green, A., "The twin failures of the CDM: recommendations for the "Copenhagen Protocol" Law and Development Review, vol. 1, ed. 2, 2009, 225 256, Headon, S., "Whose Sustainable Development? Sustainable Development under the Kyoto Protocol, the "Coldplay Effect," and the CDM Gold Standard", Colorado Journal of International Environmental Law and Policy, vol. 20, 2009, 127-156.

139 On the significant distributional consequences of the KP, see Barret, S., "International Cooperation and the Global Environment", in: Kaul, I., Grunberg, I., and Stern, M. A., eds., Global Public Goods: International Cooperation in the 21st Century Oxford University Press, New York, 1999, 192-219.

140 More details available online at <cdmpipeline.org/cdm-projects-type.htm> (accessed 5 June 2013).

141 A table for comparison of different global warming potentials of GHG gases is available online at $<$ unfccc.int/ghg_data/items/3825.php> (accessed 5 June 2013).

142 Notwithstanding, the expected amount of CERs is almost equal: $31 \%$ for the HFC, PFC and N2O projects and $34 \%$ for renewable energy projects. See statistical data at <cdmpipeline.org/cdm-projectstype.htm> (accessed 5 June 2013). 
Brazilian magnesium plant. On the other hand, there is a Spanish energy company that invested in a $61.5 \mathrm{MW}$ wind farm in South Korea. Total investment was roughly estimated to be at around USD 1.4 million in the Brazilian project and USD 123 million in the case of the Korean one. But whereas the conversion initiative creates emission reductions equal to $274,715 \mathrm{tCO}_{2} \mathrm{e}$ per year, the wind farm delivers less than a half, $112,812 \mathrm{tCO}_{2}$ e per year. ${ }^{143}$ In addition, transaction costs under the CDM mechanism may discourage small-scale renewable energy projects that are relatively less economical than the large ones. ${ }^{144}$

In spite of all the difficulties, the number of projects related to renewable technologies under the CDM scheme is growing as they progressively become cost-efficient. The legal framework of the CDM remains a powerful instrument of international cooperation and undoubtedly helps to develop an international market for renewable energy. ${ }^{145}$

\section{III.2. The birth of IRENA and the current consolidation of international cooperation}

In order to enhance and systematize international cooperation in the field of renewables, the International Renewable Energy Agency (IRENA) was founded in 2009. As provided under its Statute, the Agency has been conferred an exclusive mandate for the promotion of 'the widespread and increased adoption and the sustainable use of all forms of renewable energy'. ${ }^{146}$ Being 'a centre of excellence for renewable energy technology', ${ }^{147}$ the Agency retains a broad range of activities, such as analysis and monitoring of

${ }^{143}$ Further information on the 'Yeong Yang 61.5MW Wind Farm Project' available online at <cdm.unfccc.int/Projects/DB/KFQ1210856027.26/view> (accessed 19 February 2014). For the 'Conversion of $\mathrm{SF}_{6}$ to the alternative cover gas $\mathrm{SO}_{2}$ at RIMA magnesium production site', see <cdm.unfccc.int/Projects/DB/TUEV-SUED1239262577.48/view> (accessed 19 February 2014).

144 Transaction costs may include legal expenses, registration fees, consultants and auditors remuneration. See Chadwick, B. P., "Transaction costs and the clean development mechanism", Natural. Resources Forum, vol. 30, 2006, 256-271 and Del Río, P., "Encouraging the implementation of small renewable electricity CMD projects: An economic analysis of different options", Renewable and Sustainable Energy Reviews, vol. 11, 2007, 1361-1378, individuating also other barriers encountered by CDM projects on renewable energy (e.g. fewer economies of scale, difficulties in proving 'additionality' and the market failure determined by the absence of a market value for their contribution to sustainable development).

145 Benefits of the Clean Development Mechanism 2012, UN Framework Convention on Climate Change, 2012, 1771 UNTS 107.

146 See Statute of the International Renewable Energy Agency (IRENA), Bonn (Germany), 26 January 2009, in force 8 July 2009, Art. 3. On the Statute, see Wright, G., "The International Renewable Energy Agency: A Global Voice of the Renewable Energy Era?", Renewable Energy Law and Policy Review, vol. 4, 2011, 251-268. The creation of the agency was originally advocated by Hermann Scheer, former president of Eurosolar and the World Council for Renewable Energy. He proposed the draft for a Supplemental Protocol to the Nuclear Non Proliferation Treaty (NPT) of 1 June 1970 to be called 'Renewable Energy Proliferation Treaty' (REPT), mandating the institution of an IRENA to promote the transfer of renewable energy technology and energy efficiency, according to the principle of subsidiarity. See, Scheer, H., "Torwards a Solar Proliferation Treaty. Leaving the Global Atomic Trap", in: Stockhinger, H., Van Dyke, E., eds., Updating International Nuclear Law: Papers Derived from the Conference on the Human Right to a Safe and Healthful Environment and the Responsibilities Under International Law of Operators of Nuclear Facilities, Held in Salzburg, Austria, October 20-23, 2005 Intersentia, Antwerp, 2007, 306-310.

147 See IRENA Statute, Art. IV, a. 
renewable energy policies, ${ }^{148}$ interactions with governmental and non-governmental organisations and networks, ${ }^{149}$ advice and assistance to the Member States on various issues (including financing and technical standards) ${ }^{150}$ and the promotion of $\mathrm{R} \& \mathrm{D}$ activities through knowledge and technology transfer. ${ }^{151}$

It should be noted that there are other international organisations active in the field of renewable energy and that IRENA should coordinate its work in order to avoid the overlapping of mandates. ${ }^{152}$ Certain doubts might arise apropos of its relationship with the UN and the likelihood that it might cover part of the same activities, thus making IRENA a duplicate of a UN institution active in the renewable energy sector. In spite of the fact that IRENA's Statute mentions the importance of principles and policies of the $\mathrm{UN},{ }^{153}$ the concerns that the new Agency might lose its original purpose in the wide network of the UN institutions are groundless. None of the UN agency or program is dedicated to the sole matter of alternative energies. The United Nations Environment Program (UNEP) has a general task to assist developing nations in all kinds of environmental activities and to advise on policies that are not limited to climate change mitigation but include wise environmental management and technology transfer for sustainable development. ${ }^{154}$ Another UN body, the United Nations Development Program (UNDP), focuses on development and collaborates with poor countries in capacity-building to integrate environmental considerations into their domestic policies. ${ }^{155}$ However, the United Nations Industrial Development Organisation (UNIDO) promotes mainly cleaner energy and environmentally sustainable use of electricity in the industrial and agro-processing sectors. ${ }^{156}$

One institution having common operational ground with IRENA is the IEA. However, given its limited membership (OECD countries only) and its extensive work in other energy-related domains (i.e. energy security, economic development through stable energy supply, analysis of the traditional energy sources employment), renewable energy issues do not constitute its main focus. ${ }^{157}$ Some might recall that other two institutions operate in the renewable energy sphere, the Renewable Energy and Energy Efficiency Partnership (REEEP) and the Renewable Energy Policy Network for the 21st Century

148 Id., Art. IV. A.1.a.

149 Id., Art. IV. A.1.b.

150 Id., Art. IV. A.1.c, d, e and f.

151 Id., Art. IV. A.1.g and h.

152 As stressed by Wright, G., supra nt. 146, such risk is minimal for those who considered the agency as a peculiar organisation playing an 'epistemic' role instead of a legal and financial ones carried out by preexisting bodies, as Meyer, T., "Epistemic Institutions and Epistemic Cooperation in International Environmental Governance", Transnational Environmental Law, vol. 1, ed. 2, 2013, 38-43.

153 See IRENA Statute, Art. IV. B.1.

154 UN GA resolution A/RES/27/2997 of 15 December 1972 on 'Institutional and financial arrangements for international environmental cooperation'.

155 UN GA resolution A/RES/20/2029 of 22 November 1965 on 'Consolidation of the Special Fund and the $\mathrm{E} \quad$ panded Program on Technical Assistance in a United Nations Development Programme'.

156 UN GA resolution A/RES/21/2152 of 17 November 1966 on 'United Nations Industrial Development Organization'.

157 Agreement on an International Energy Programme of 17 November 1984, available online at <ebvoil.org/cms/pdf/iep.pdf> (accessed 19 February 2014). An IEA/IRENA partnership agreement was signed in January 2012. Enhancing inter-agency cooperation, as suggested, is a way to reduce overlapping risks, see Van de Graaf, T., "Obsolete or resurgent? The International Energy Agency in a changing global landscape", Energy Policy, vol. 48, 2012, 233-241. 
(REN21), potentially challenging IRENA initiatives. However, it must be recalled, both REN21 and REEEP are nongovernmental organisations. ${ }^{158}$ Whereas REN21 has indeed certain goals in common with the Agency, being a multi-stakeholder network and a fine platform for knowledge exchange and joint action development, REEEP is mostly involved in hands-on operations and has so far gathered funds for over 180 clean energy projects in 58 countries (on the contrary, IRENA's Statute does not contemplate any provision on direct financing of green projects).

Recognising the possibilities that could stem from the collaboration with these two organisations, on the basis of its Statute (Article XIV), ${ }^{159}$ IRENA forged strategic partnerships by signing two joint Memoranda of Understanding (MoU). In August 2011 the Agency and REEEP agreed on a partnership to cooperate, exchange information and expertise and implement various programs and best practices. ${ }^{160} \mathrm{~A}$ closer collaboration between the Agency and REEEP will be beneficial as the latter has already secured a group of donors to appropriately fund the projects and has acquired the necessary field experience. IRENA, in turn, could guarantee fundraising to seek a financing support from other states and non-governmental organisations. Later, in January 2012 IRENA and REN21 signed a MoU in order to enhance their mutual efforts in the deployment of renewable energy. ${ }^{161}$ The above-mentioned partnerships will help IRENA expand its range of activities, giving an impulse for developing new ways of promoting renewable energy worldwide.

However, establishing relationships with other organisations 'to ensure added value in the work with external partners' 162 is not the only goal of IRENA. Pursuant to its Statute and 'Medium-term Strategy', released in January 2013, the Agency operates independently as well. The 'Strategy' expressly states a mission of IRENA which consists in being 'the principal platform for international cooperation, a centre of excellence on renewable energy and a repository of policy, technology, resource and financial knowledge' ${ }^{163}$ and in supporting 'countries in their transition to a renewable energy future'. ${ }^{164}$ Basically the mission represents a concise version of Article IV of the Statute

158 REEEP is a non-profit organization operating in developing countries in order to support clean energy projects. It acts as catalyst for investments in renewable energy. Its field operations are supported by various governments (e.g. certain EU countries, Australia, Canada, New Zealand, Switzerland and the US), as well as financial institutions (e.g. the OPEC Fund for International Development). See more REEEP, Program \& People, available online at <reeep.org/program-peoplelivepage.apple.com> (accessed 5 May 2014). REN 21 is a non-profit association which tries to connect governments, international organisations, industry and academia in an effort to promote joint action in the renewable energy deployment. Its primary function relates to providing information and policy analysis. See more REN21, 'About REN21', available online at <ren21.net/AboutREN21.aspx> (both accessed 19 February 2014).

159 Mandating that: 'Subject to the approval of the Assembly the Council shall be authorised to conclude agreements on behalf of the Agency establishing appropriate relations with the United Nations and any other organisations whose work is related to that of the Agency'.

160 See REEEP Press Release, available online at <irena.org/DocumentDownloads/ FinalPRcooperationIRENA-REEEP.pdf $>$ (accessed 19 February 2014).

161 See Ren21 \& IRENA, Press Release of 18. January 2012, available online at <ren21.net/Portals/ 0/documents/Resources/REN21-IRENA_Cooperation_signed.pdf> (accessed 19 February 2014).

162 Decision on the Work Program and Budget for 2013, IRENA Doc. A/3/DC/13, 14 January2013, para. 12.

163 Medium-term Strategy of IRENA: Report of the Director-General, IRENA Doc. A/3/25, 14 January 2013, para. 12 .

164 Ibidem. 
and gives the essence of IRENA's raison d'être. The 'Strategy' moreover elaborates and articulates in detail the specific strategic objectives of the Agency. Article II of the Statute in fact gives only a general idea of what IRENA's objectives are: promotion of 'the widespread and increased adoption and the sustainable use of all forms of renewable energy'. ${ }^{165}$

In its turn the 'Medium-term Strategy' outlines three main equally important objectives, three pillars, upon which IRENA should build its leadership in renewable energy cooperation. First, the document reaffirms the primary goal of becoming a centre of excellence for renewable energy in order to provide a comprehensive existing and IRENA-originated information and to avoid an information overload as well as to organise proactive communication between stakeholders providing analytical and policy advice. ${ }^{166}$ Second, the Agency should become a 'renewable energy advisory resource for countries' in order to assist them with the advanced technical knowledge and to help enhancing institutional, legal and business frameworks for a better investment environment. ${ }^{167}$ Third, IRENA envisages itself as a 'network hub of country, regional and global programs' as a means to create transparency over financial support mechanisms and facilitate cooperation between different stakeholders on various levels. ${ }^{168}$ As a matter of fact, the lack of information hinders investments. An array of financial mechanisms might be in need of a centralised coordination. A step in the right direction, chosen by the Agency, is a creation of a unified database with all the possible financial solutions (including the Global Environmental Facility, the World Bank, the UN backed funds and private sector grants) for various potential investors.

On the basis of the objectives and the provisions of the Statute, the Agency's practice has been developed in three main areas: 1) knowledge, policy and finance issues; 2) country support and partnerships; 3) promotion of innovation and spread of information on new technologies. One of the latest initiatives, developed in collaboration with the UNEP, concerns the creation of a Global Atlas for Solar and Wind Energy. Internetbased maps and data on solar and wind energy resources will provide systematic and reliable information helping to identify areas with high renewable energy potential and to direct cooperation.

Another important activity initiated by IRENA is Renewables Readiness Assessments (RRAs). ${ }^{169}$ Initial studies were conducted in 2011 in Senegal, Mozambique and Kiribati, two African nations and a small island nation in the Pacific, where renewable energy was already deployed but where further development would be needed. ${ }^{170}$ The fourth RRA report concerned the Caribbean Island of Grenada, whose government is willing to accomplish an ambitious transition from an oil-dependent economy into one where

165 See IRENA Statute, Art II.

166 IRENA Doc. A/3/DC/13, supra nt. 162, paras. 14-17,

167 Id., paras. 18-24.

$168 I d$., paras. 25-27.

${ }^{169}$ RRA presents, in a form of a report, an evaluation of a country's renewable energy situation in its whole and suggests necessary actions to improve the overall state of affairs in the renewable energy sector.

170 For more details see Kiribati Renewables Readiness Assessment 2012: Exploring sustainable and secure pathways towards energy independence, IRENA, 2012, Senegal Renewables Readiness Assessment 2012, IRENA, 2012, Mozambique Renewables Readiness Assessment 2012, IRENA, 2012, Grenada Renewables Readiness Assessment 2012,IRENA, 2012, available online at <irena.org/Publications/ReportsPaper.aspx?mnu=cat\&PriMenuID=36\&CatID=141> (accessed 19 February 2014). 
renewables would be a primary energy source. In each case the RRAs delivered evaluation and analysis of national potential and conditions for the deployment of renewables and the development of a renewable energy market. It aimed at giving a comprehensive vision of how a State could harness clean energy and contribute to its own economic development while becoming energy independent. An RRA report usually assesses all economic aspects related to energy (i.e. transportation and electricity generation) and the renewable energy endowment of the country. It moreover identifies and recommends particular actions to scale up the use of alternative energy. Alongside the advice services, IRENA is also committed to the promotion of educational programs in order to assist Member States in acquiring specialised technical skills and qualified labour. For this purpose, IRENA's Renewable Energy Learning Partnership (IRELP) was created. It intends to bridge a gap in the information on existing training in the renewable energy sector, and to provide access to learning materials and to enable interaction between education providers.

\section{III.3. The emergence of transnational private sector cooperation on renewables}

Although IRENA is gaining ground in the field of the international cooperation, it is worth noting that there additionally exist separate and independent initiatives - an outcome of voluntary collaboration among States and non-State actors. The so-called 'voluntary carbon markets' were born and are having success among developed countries (especially in the U.S. where no federal cap-and-trade scheme exists). ${ }^{171}$ State willingness to cooperate in spite of difficult global climate negotiations ${ }^{172}$ made possible the development of a dozen of new voluntary programs. The demand in these markets is driven by companies autonomously choosing to offset their own emissions by choice. In 2011 the volume of transacted carbon credits barely reached a $0.1 \%$ of the global carbon markets, yet it is growing in value terms and proving the readiness of private sector to contribute to the green economy. ${ }^{173}$ Renewable energy projects as a category have generated $45 \%$ of all volumes of carbon credits, with wind technologies as the dominant type. ${ }^{174}$ Most transacted wind credits (65\%) were generated in Asia and Turkey and the transaction volumes of the US-based renewable energy projects have grown. ${ }^{175}$

Europe is one of the most active participants in the environmental initiatives and distinguished itself in the field of renewables as well. Two examples can illustrate its readiness to promote the development of clean energy worldwide: the Small Developing Island Renewable Energy Knowledge and Technology Transfer Network (DIREKT) and

171 Ecosystem Marketplace \& Bloomberg New Energy Finance, 'Developing Dimension: State of the Voluntary Carbon Markets 2012'.

172 CMP8 established a second commitment period (1 January 2013 - 31 December 2020) pursuant to the mandate of the Durban Platform for Enhanced Action (COP17/CMP7), requiring to 'adopt a protocol, another legal instrument or an agreed outcome with legal force as soon as possible but no later than 2015', see Decision 1/CP.8, Amendment to the Kyoto Protocol pursuant to its Article 3, paragraph 9, the Doha Amendment, UN Doc. FCCC/KP/CMP/2012/13/Add.1, 28 February 2013.

173 Peters-Stanley, M., Hamilton, K., "Developing Dimension: State of the Voluntary Carbon Markets 2012", Ecosystem Market Place/Bloomberg Energy Initiative, 10, available online at <www.foresttrends.org/documents/files/doc_3166.pdf> (accessed 8 March 2014).

174 Id., 17.

175 Id., 18. 
the DESERTEC project. ${ }^{176}$ The former is an EU-funded cooperation scheme under the ACP Science and Technology program. It originates from the collaboration between universities in Germany, Fiji, Mauritius, Barbados and Trinidad and Tobago with a goal to enhance sustainable cooperation and technology transfer by filling a gap in a scarce expertise and an insufficient access to the latest technologies. In its turn, DESERTEC objective is to strengthen the renewable energy capacity (mainly of solar energy) by constructing solar-thermal power plants in desert areas. The electricity generation from those plants will supplement the electricity coming from already existing intermittent renewable energy generators (PV and wind turbines). The project was initiated by the DESERTEC Foundation, an NGO established in 2009 by the German Association of the Club of Rome and a group of scientists, economists and politicians interested in alternative energy. The DESERTEC Concept was created as a result of their collaboration. It consists in harnessing renewable energy in places where it is largely and almost constantly available and, once converted into electricity, transmitting it to centres of demand. The concept was first developed for the MENA (Middle East and North Africa) region and aimed at interconnecting Europe and Northern Africa in order to export electricity generated from renewables to the European countries thus pursuing two goals: to guide developing countries along the sustainable development path while bringing more clean energy to EU countries. Early activities took place in Morocco, Tunisia and Egypt and mostly concerned the development of technical skills and expertise. The DESERTEC Foundation, for instance, has recently participated in the TuNur-project, ${ }^{177}$ an initiative designed to produce clean energy in the Tunisian desert and export it on the other side of the Mediterranean. ${ }^{178}$ All these activities demonstrate the existence of an expanding interest towards the development of transnational renewable energy networks. Private initiatives thus coexist alongside States and international organisations by virtue of their inherent characteristics (more flexibility, efficiency, productiveness) can further stimulate the global expansion of the renewable energy sector.

\section{Conclusions}

Renewable energy generation is key for the attainment of sustainable development and climate stabilisation. Empowering the world through the use of renewable resources certainly stands amongst the biggest challenges facing the international community. Nevertheless, States are not always keen to embrace a global basis for renewables as demonstrated by many soft law instruments. More significantly, renewable energy developments are not supported by any legally binding norm, let alone any ad hoc agreement, entailing a detailed discipline on renewable energy generation. On the contrary, as it has been discussed, international binding norms negotiated for different purposes and in different fora can incidentally limit the policy space of States willing to pursue renewable energy goals.

\footnotetext{
176 For further details, respectively see < direkt-project.eu> and < desertec.org > (both accessed 19 February 2014).

177 TuNur Ltd. is a joint-venture formed by NurEnergie, a multi-technology solar power plant developer and Tunisian investors. It has been developing the TuNur Project, an export initiative between Europe and Tunisia.

178 More information about the TuNur Project can be found at <tunur.tn> (accessed 19 February 2014).
} 
As suggested by the outcome of the cases chosen here for their either direct or indirect relevance to the production of energy from renewable sources, such activity, although per se desirable, must be carried out consistently with State obligations in the human rights area and must guarantee an effective exercise of environmental procedural rights from the public. Furthermore, in the absence of internationally binding instruments setting a positive discipline for renewable energy generation, the pursuit of renewable energy goals through national policies cannot alone justify the departure from binding international trade rules. Any international legal development fostering renewable energy generation should integrate these concerns to the greatest extent possible.

However, international cooperation in the renewable energy sector shows positive trends of development. The past reluctance to address clean energy needs, as observed in the Kyoto Protocol-related negotiations, brought certain difficulties in the deployment of the renewable energy projects under the CDM. Given the falling costs of clean technologies and an ever-growing interest in preventing negative effects from climate change, any new climate change agreement should be framed to give priority to renewable energy investments. Meanwhile IRENA has been established and developed its initial practice, making its way through a network of existing international organisations operating in the field of renewables. Today IRENA has a solid strategic base allowing the Agency to carry out its programs and activities in a transparent and independent manner, due also to the various partnerships it has built. IRENA has positioned itself as a remarkable platform for international cooperation in renewables but further analysis will be required to see how the Agency succeeds in reaching its objectives. Nonetheless, cooperation is not confined to States' initiatives, characterised by slowness and difficulty in finding compromise between multiple interests. Indeed, more flexible private transnational cooperation may also prompt further development of renewable energy amongst State and international organisations. 